\title{
Commercial Contracts in Soviet Law
}

\author{
Harold J.Berman*
}

THE achievements of the Russian Revolution are nowhere more striking than in the field of economic development. In one generation a backward agricultural country, occupying a colonial position in relation to Western Europe, has been transformed into a world industrial power. This accomplishment is no accident, but a direct consequence of the philosophy and dynamic of the Revolution with its primary concern for a planned and integrated economy.

During the first two decades of the Revolution, the emphasis on economics was not confined to the processes of production and distribution; it permeated almost every phase of Soviet life. The whole of history and society was viewed in the light of economic determinism and economic integration. It was believed that with the achievement of a classless society under socialism, mankind would finally be free of all the traditional institutions of the past. The family as a juridical entity would disappear ${ }^{1}$ prisons would become superfluous. ${ }^{2}$ Money, contracts, and other familiar commercial concepts would be replaced by direct orders of planning and regulating agencies. ${ }^{3} \mathrm{Law}$ itself, which had developed as a means of regulating capitalist market relations, would together with the state "wither away"."

*A.B., Dartmouth College, 1938; Certificate of Graduate Studies in Legal History, London School of Economics and Political Science, 1939; M.A. 1942, LL.B. 1947, Yale University. Mr. Berman joins the faculty at Stanford Law Scloool this Fall as Assistant Professor of Law.

1 Berman, Soviet Family Law (1946) 56 YaLe L. J. 26.

2 Berman, Principles of Soviet Criminal Law (1947) 56 YALE L. J. 803.

3 "Wreckers on the ideological front argued that the growth of planning in the national economy signified the end of legal form. Economic ties would be establislied by direct order of planning and regulating organs. The significance of contracts would vanish. ... The theory of the immediate witlering away of trade and money was developed both in economic and in other literature." Aleksandrov, The Socialist System of Economy, ARBITRAzH [1937] No. 20 (in Russian) 15.

4 Under the "commodity exchange" conception of law espoused by pre-1936 Soviet jurists under the leadership of Pashukanis, all law is a refiection of the relations of persons who deal in commodities on the market. Thus contract law is fundamental to every other brancli of law, and its principle of the agreement of the intentions of the parties is transferred to all other spheres-to constitutional law, for example, where rights are construed as analogous to rights of individuals in the goods with which they deal; to criminal law, where the principle of retribution expresses the claims of the commodity dealer to compensation proportional to his losses. Pashukants, Generac Theory of 
In 1936 Stalin declared that socialism had been achieved; at the same time he announced the promulgation of a new Constitution, and stated that "we need stability of laws now more than ever." These words introduced a profound upheaval in Soviet economic and legal thought. Law was extricated from economic materialism and declared to have independent values of its own. Previous articles have shown the repercussions of this restoration in the fields of family law and criminal law. ${ }^{6}$ In the law governing the commercial relations of state busmess enterprises (factories and plants, wholesale bases, retail shops) the consequences have been equally far-reaching. This article is devoted primarily to an investigation of these consequences.

However, to understand thein it is necessary to make certain preliminary inquiries: first, into the legal status of a Soviet state business enterprise (its relation to the organs of public control, the extent of its operational autonomy, its "juridical personality"); second, into the distributive systein (wholesale and retail trade, the planning of distribution, the planning of contracts); and third, into the general principles of Soviet contract law (the adjudication of disputes between state business enterprises, contract law in the civil code, doctrimes of nullity and fault). On this foundation we shall approach, fourth, the general principles and specific characteristics of contracts of purchase and sale between Soviet state business enterprises.

THE JURIDICAC PERSONALITY OF THE STATE BUSINESS ENTERPRISE

\section{Public control of Soviet economic life.}

The integration of political and economic authority is a basic concept of the Soviet Constitution, which provides for state ownership of the means of production ${ }^{\tau}$ and the direction of economic life by state economic plan. ${ }^{8}$ The Council of Ministers, which is respon-

LaW (1924) (in Russian). Cf. SchuEstNGer, SOVIET Legal TheORY (1945) 154. In preparing for the "withering away" of all law under socialism, Pashukanis and his followers advocated the gradual replacement of civil law by economic law. Cf. GinTsiono and Suvorov (editors) QUESTIONS of SOvIET ECONOMTC LAW (1933) (in Russian) 16, where the table of contents of a possible Economic Code for the U.S.S.R. is proposed. These ideas were closely associated with the radical ideas on planning held by the left wing of the Communist Party. See Aleksandrov, Rooting Out the Remnants of the Pashukanis 'Theoretics' in the Theory of Law, ARBITRAZH [1937] No. 15 (in Russian) 14.

5 Stalin, Report on the Draft Constitution at the Eighth Extraordinary Conference of the V.K.P. (b) (1936) (in Russian).

${ }^{6}$ Supra notes $1,2$.

T U.S.S.R. CoNsT., Art. 4.

8 Ibid. Art. 11. 
sible for making and executing the plan, is the highest executive and administrative organ of the state; its decisions and orders are binding throughout the territory of the U.S.S.R. ${ }^{9}$

The Council of Ministers is composed chiefly of the industrial, agricultural, mercantile, and financial leaders of the country ${ }^{10}$ and is served by four main administrative bodies: ${ }^{11}$ the State Planning Commission (Gosplan) which draws up the Five-Year, annual, and quarterly plans for the Soviet Union as a whole; ${ }^{12}$ the State Bank (Gosbank), which supervises the entire credit and financial structure of the national economy; ${ }^{13}$ the Economic Council (Ekonomsoviet), which coordinates the work of the various economic ministries and controls trade among them; ${ }^{14}$ and the Council of Defense. The chairmen of these bodies are members of the Council of Ministers. ${ }^{15}$

Ibid. Arts. 64, 67, 68(b). Prior to 1946 the Council of Ministers was called the Council of People's Commissars, and ministries were called People's Commissariats.

10 Ibid. Arts. 77, 78.

I1 BIenstock, Schwarz and Yugow, Manageatent in Russian INdustry aNd AGRICULture (1944) 4 et seq.

12 Gosplan was created in 1921 to serve the Council of Labor and Defense, which in turn was an administrative body of the Central Executive Committee. (The Central Executive Committee performed the major governmental functions prior to the 1936 Constitution.) Not until the close of the N.E.P., however, were the decisions of Gosplan made binding upon all state planning organs. Decree of June 8, 1927, CorL. LAws, U.S.S.R. (1927) No. 33, art. 373. In 1931 it was placed directly under the Council of People's Commissars, and its chairman was made a member of the Council. Decree of Feb. 3, 1931, CoLI. LAws, U.S.S.R. (1931) No. 8, art. 86. On the basis of general directives from the Central Committee of the Communist Party and the Council of Ministers, Gosplan draws up plans for the various sectors of economic activity (heavy industry, hight industry, transport, agriculture, etc.) and for the various territorial regions. It amalgamates these partial plans into a single Plan, which it submits to the Council of Ministers for approval. It also supervises the fulfillment of the plans by the ministries and by the largest individual plants. Decrees of Feb. 2, 1938 and Dec. 31, 1940, Corr. LAws, U.S.S.R. (1938) No. 41 ; (1940) No. 27. Employing about 1000 planning officials, Gosplan is divided into fifty-four so-called "functional" and "production" departments; the former lay out plans for the erection of new factories and works, determine production figures, raw material and manpower requirements, and financial needs; the latter plan and supervise separate branches of industry. The activities of "functional" and "production" departments in practice overlap. See Berisstock et al., op. cit. supra note 11 , at 47 et seq.

13 Infra note 22.

14 The planning of distribution, infra.

15 The chairmen of the Committee on Arts and the Committee on Higher Education are also members of the Council of Ministers. Administrative organs which report to the Council but are not represented on it include: the All-Union Consumers' Cooperative (Tsentrosoiuz), the Board of Manpower and the Committees on Standards, the Cinema, Technical Personnel, Geology, Forests, and Weights and Measures. Cf. Bienstock et al., op. cit. supra note 11, at 5 , for diagram of the Council of Ministers. 
Of the forty-mine members of the Council of Ministers, ${ }^{10}$ thirtyfour are economic ministers: heads of particular industries (oil, iron and steel, aircraft, etc.); heads of systems of communications (railway, maritime fleet, telegraph and telephone, etc.); heads of spheres of economic activity such as foreign trade, internal trade, and finance. An economic ministry is divided into chief admimistrations (glavki) for sub-industries, or for areas, or for both. Certain large glavki are further subdivided into trusts. The heads of both these administrative subdivisions are appointed by the minister. A typical ministry, glavk, or trust contains departments of planning, finance, procurement and sale, construction, manpower, and accounting. The general directives and plans of the Council of Ministers and its administrative organs are miplemented by more specific directives and plans of ministries, glavki, and trusts. ${ }^{1 \pi}$

The individual operating units are owned by the state, but they are carried as assets of the ministry to which they are assigned. The manager or director is appointed by the ministry. Thus he is a state official operating a given portion of state property in accordance with the directives and plans issued by superior state economic agencies.

\section{Operative independence of the state business enterprise.}

Despite this vast superstructure of public control, the autonomy of the individual producing or trading unit has been increasingly emphasized during the past decade. Planning has become more flexible to suit regional and local needs. ${ }^{18}$ The powers of the director have been expanded, and the various department heads of an enterprise are responsible to him. ${ }^{19}$ With this increase in the director's authority

${ }^{16}$ This number is not constant. Only in recent years has the number of ministries been multiplied to its present proportions.

17 BueNsTock et al., op. cit. supra note 11, at 7 et seq.

18 By a Decree of Jan. 7, 1941 (Laws and Ordinances of the U.S.S.R. [1941] No. 40) almost all planning of production and sale of consuners' goods by local industries and handicraft cooperatives (artels) was transferred to local authorities. Central boards for the supervision of artels were abolished. In 1940 nine territorial departments were added to Gosplan, to supplement the two departments of Regional Planming and Geographic Distribution of Plants which had previously existed. Also, important measures were taken to improve the connections between local planning committees and republican organs.

19 Prior to 1934 the various departments of a factory (accounting, planning, financing, procurement, sales, and labor and wages departments) were subordinate to corresponding departments of superior planning and regulating organs. This so-called "functional" system was abandoned in a drive against bureaucracy and "depersonalization". Cf. Model Statutes for Enterprises in Heavy Industry, STEex [1934] No. 11-12 (in Russian) 106-111. The director is described as "the chief leader of the cnterprise 
there has been a corresponding increase of liability for failure to perform the assigned duties. ${ }^{20}$

Moreover, in their relationships with each other and with superior economic organs, state business enterprises have been put on a basis of "business accountability" (khozraschet), a term greatly stressed by both economists and jurists. Business enterprises enter into commercial relations independently, are responsible for their debts, keep accurate accounts, and measure their success largely in terms of their profit. ${ }^{21}$ Business accountability is closely linked historically ${ }^{22}$ and analytically with the system of bank credit. All financial dealings over 1000 rubles inust be carried on through state banks, which are thus placed in the position of financial inspectors for the government. They have general supervisory authority over office organization and and main organizer of production .... His orders are to be fulfilled without fail by all personnel of the enterprise as well as by all persons working on the premises." One of the most important elements of the director's powers is his control over the so-called "director's fund", into which goes four per cent of the net planned profits of the enterprise and fifty per cent of profits beyond plan (sixty-five per cent in the case of trading enterprises). Not less than one-half of the director's fund must be used for additional housing of workers and employees, the remainder going into other services, supplementary equipment, rationalization and technical education, and, above all, bonuses for outstanding work. The agreement of the plant committee of the labor union is required for most of these expenditures. Shkundin, The Legal Status of Property under the Administration of State Business Enterprises, ARBITRAZE [1938] No. 19 (in Russian) 16. Cf. Hazard, Soviet Government Corporations (1943) 41 MrcH. L. Rev. 850.

20 Under "economic crimes", Soviet criminal law includes thriftlessness (any intentional or careless act detrimental to socialist economy), production of goods of bad quality, malicious nonfulfillment of contracts, and breach of technological discipline (failure of leaders of production to fulfill their obligations). The penalties for such crimes were increased prior to and during the war. Cf. Arr-UNION INSTrTuTE of JURmiCAI ScIence, Crmonal LaW, Spectal Part (1943) (in Russian) 320 et seq. For negligent or intentional production of incomplete, substandard or defective goods, a penalty of five to eight years imprisoninent is imposed. CRIMINAL CoDE, R.S.F.S.R., art. 128(a), as amended by Decree of July 10, 1940, JourNax OF THE SUPREMIE SOVIET OF THE U.S.S.R. (1940) No. 13 (in Russian).

21 It is not to be supposed, of course, that independence, profits, etc., are considered ends in themselves. Moreover, it is true that "the basic purpose" of business accounability "is not to make a profit on an investment but to control the use of state property." Hazard, op. cit. supra note 19, at 866 . But it is striking that in order effectively to control the use of state property, contracts and profits have been reintroduced and re-emphasized.

22 The Credit Reform of the early 1930's "consisted in the liquidation of commercial credit and its replacement exclusively by direct bank credit. It was directed toward increasing the purchasing power of the ruble, toward strengthening its role as the means of increasing the accumulation of socialist enterprises, as a method of strict supervision of financial and contractual discipline and the inculcation and strengthening of business accountability." MozHerko and SHKundar, ARBITraze IN THE SOVIET Econonty (2d ed. 1938) (in Russian) 4. 
financial operations. However, in accordance with the policy of business accountability, the banks are not permitted to transfer funds from one account to another except on the order of the depositor. The development of this direct credit relationship has further increased the operative independence of the individual state business enterprise.

\section{Doctrine of the juridical person.}

To give legal expression to the principle of business accountability, Soviet jurists have in recent years greatly extended the doctrine of the juridical person. ${ }^{23}$ In the first decade of the Revolution all factories in each industry were assembled into state trusts, which alone were given juridical personality. Although they were subordinate to the Supreme Economic Council, these trusts exercised considerable independence. They were liable for their debts to the extent of their turnover capital, and no one could acquire property from them except by contractual agreement. ${ }^{24}$ They possessed, used and disposed of the property assigned to them by the state and were subjects of rights and duties under civil law. The productive units belonging to the trust, however, were completely subordinate to it and incapable of exercising independent legal rights.

After 1928 the trust became first an instrument of the planning organs, then merely a supervisory organization, and was finally for the most part eliminated altogether ${ }^{25}$ whereas, especially in the past decade, the productive units have been given nuore and more independence. Where the trust has been retained, relations between it and subordinated enterprises are now on a legal basis, ${ }^{26}$ as are the relations between the glavk and its enterprises. Both the glavk and trust are obliged to present to the factory necessary materials and equipment for the fulfillment of production tasks. Losses which arise from failure to perform this obligation are borne by the glavk or trust. ${ }^{27}$

23 Bratus, On the Question of the Development of the Juridical Personality of the Soviet State Enterprise, ACADEMTY of SCIENCES of THE U.S.S.R., QUESTIONS OF SOVIET Crvin LaW (1945) 5.

24 Crvin CoDE, R.S.F.S.R., arts. 13, 19.

25 Bratus, op. cit. supra note 23 , at 10 et seq.; Shlsundin, op. cit. supra note 19 , at 17 .

20 Bratus, op. cit. supra note 23 , at 27.

27 Where a factory orders a machine from a manufacturer in reliance on a previous promise by the glavk of assignment of funds for such machine, the factory, in a suit against it by the manufacturer for the price of the machine, may have the glavk ioined as party defendant; and the glavk is hable "as guarantor" for the purchase price plus a penalty for delay of payment. (The fact that the glavk was not authorized by the state budget to assign funds for such machine, and that it did so through irresponsible 
Losses resulting from the unexcused failure of the enterprise to deliver the finished product on time are borne by the enterprise. Accounts between the trust or glavk and the productive enterprise are kept on the basis of individual orders. Moreover, the business enterprise, whether subordinate to a glavk or to a trust, may independently conclude contracts in its own name, keep checking accounts in credit institutions, and possess, use and dispose of its property as an independent subject of law.

Thus state business enterprises seem to fulfill the requirements of juridical persons under the Civil Code. ${ }^{28}$ However, corporate charters have hitherto been reserved for enterprises created directly by the ministry or glavk. ${ }^{20}$ The chief remaining distinction between incorporated and unincorporated business-accounting enterprises seems to be that the trust is liable for the debts of its enterprises in the event of their insolvency. ${ }^{30}$ In recent Soviet legal literature enterprises of trusts, glavki, and ministries have been treated as juridical persons. ${ }^{31}$

acts of employees does not release it from liability.) Limen Factory F. Engels v. Machine Construction Plant Artem, Arbitrazer [1939] No. 13 (in Russian) 32.

28 "Combinations of persons which may, as such, acquire rights in property, enter into obhigations, sue and be sued in court, shall be recognized as juridical persons." Crvn CODE, R.S.F.S.R., art. 13. "State enterprises . . . which are conducted according to business accountability and not financed out of the state budget shall enter into commerce as independent juridical persons not connected with the treasury. Only property which is within their free disposition, i.e., which is not excluded from commerce by arts. 21 and 22, shall be hable for their debts." Ibid. art. 19. The civil codes of the various republics date from the N.E.P. period (1921-1928); at present an All-Union Civil Code is in process of preparation.

29 "A juridical person must have a charter or statute issued, and in appropriate instances registered, by a competent organ .... The legal capacity of a juridical person arises from the monient of the issuance of its charter (statute) or, in those instances where the law requires registration, from the moment of such registration." Crvx CODE, R.S.F.S.R., art. 14.

30 "A business-accounting production enterprise (of a trust) is an independent subject of property rights and bears independent responsibility within the limits of the capital assigned to it .... . But this obligation does not free the trusts from material liability for the debts of enterprises which have entered into its composition in the event of the proved incapacity of such an enterprise to pay." Moscow Commercial Purchasing Base of Soiuzlesprodtorg v. Trust of Local Industry of Sokolnicheskii District, ARBITRAzI [1938] No. 20 (in Russian) 24, in which it was held that the trust was responsible for all the debts of a bankrupt factory belonging to it and not merely those which could be met with the remaining assets of the factory.

31 Bratus, loc. cit. supra note 23. But see SCHCESINGER, op. cit. supra note 4, at 247 et seq., where it is contended that the relationships between an enterprise and its superior organs, or between two enterprises, are administrative in nature. The logical conclusion of Schlesinger's argument would seem to be a return to the so-called economic law of the pre-1936 era, and the evidence he adduces represents chiefly survivals of that time. 


\section{THE DISTRIBUTTVE SYSTEM}

An increasing decentralization of the processes of distribution has accompanied the development of the business accountability and juridical personality of the state business enterprise. Direct contracts between business enterprises have during the past ten years assumed major importance. A preliminary investigation of the system of distribution in Soviet economy is necessary to understand the new significance of contracts and their relation to planning.

\section{Wholesale and retail trade. ${ }^{32}$}

The attempts under the First Five-Year Plan (1928-1932) to eliminate the wholesaler proved unsuccessful, and his functions are now allocated to three major agencies: the legally autonomous torgi (comprised of both wholesale and retail units) handle consumer goods and agricultural products in the cities; the prombazy, a system of wholesale bases, chiefly distribute industrial goods; and consumer cooperatives serve the rural areas.

In the case of mass-consumption products, the sales board ( $s b y t$ ) of the producing enterprise generally deals either with the procurement board (snab) of the ministry or glavk to which it belongs, or with the prombazy. The ministry or glavk generally sells the largest part of its products to the prombazy; however, it may also sell selected portions to large city department stores, to torg wholesale enterprises, and to cooperative wholesale enterprises. The prombazy sell to large department stores and to torg and cooperative wholesalers; the wholesalers supply their respective retail shops. ${ }^{33}$ However, variations in this general pattern are permitted and even en-

32 See especially Hubgard, Soviet Trade and Distribution (1938) 41 et seq., 79 et seq.

33 "In pre-war Russia retailing enterprises, from the big city shops to the small country storekeeper, bought their supplies partly from the manufacturer direct and partly from wholesale merchants. The larger the retailer the more likely he was to buy direct from the manufacturer, because he was in a position to take large parcels of uniform goods and get better terms than from the merchant who had to make his middleman's profit. This system resulted in manufacturers establishing their own wholesale warehouses all over the country alongside the establishments of the wholesale merchants. And since it was the custom for traders in the same sort of goods to congregate in the same quarter, it was quite possible for a retailer to buy identical goods from the manufacturer's warehouse or from a merchant's warehouse next door .... In Soviet Russia, whether by deliberate design or not, a system of wholesale distribution has been evolved somewhat similar to the above ...." Ibid. 79. 
couraged, and direct sales by the factory to the larger torg retail shops have become more and more frequent.

The transfer of producers' goods and other products not for mass consumption may be made directly by the sales board of the producing factory to the procurement board of the consumer; or the producing factory may sell to its ministry or glavk which in turn may deal either with the consumer factory or with the consumer ministry, glavk, or trust. The factory, ministry, or glavk-on either side or both-may deal through prombazy.

\section{Planning of distribution. ${ }^{34}$}

Plans of distribution begin with the presentation of applications (zaiavki) concerning requirements for the coming year by busmess enterprises, both consumer and producer, to the superior organs. The applications are examined and corrected and then sent to the republican and all-union ministries, whence they are submitted finally to Ekonomsoviet and to Gosplan. In this way the applications move up from the immediate producers and consumers to the highest planningregulating organs.

In issuing plans of distribution, Ekonomsoviet (on the basis of information accumulated by Gosplan) distinguishes first between producers' goods and consumers' goods. Producers' goods are classified according to the degree of their scarcity and urgency into "funded" products, "quota" products, and "decentralized" products. (1) "Funded" products are allocated by Ekonomsoviet to so-called "independent fundholders" (ministries, republican councils of ministers, certain other organizations of consumers), which in turn allocate the products among their subordinate organs (glavki, trusts, etc.), and these assigu portions to their various enterprises. Ekonomsoviet also determines which ministries or glavki shall supply the "funded" products, and these in turn determine which of their subordinate enterprises will manufacture and deliver thein to the given customers. The consumer enterprise then presents to the supplier enterprise specifications and orders, based on planned apportionment, which are then subject to agreement between the two enterprises. (2) The allocation of "quota" products is by contingents (quotas) to various industries or various regions; the producer ministry may supply these products to any individual user as long as the quota

${ }^{34}$ Shkundin, Planned Task and Contractual Obligation, SovIET STate ANo LAW [1940] No. 7 (in Russian) 84. 
allotted to the user's industry or region is not exhausted. (3) "Decentralized" products, which include scarce products of agriculture that are used industrially and products of local handicrafts and local industries, are purchased directly by retail torg $i$ and cooperatives without plans issued from above.

The classification of mass-consunption goods is along similar lines. So-called "planned goods" are allotted among the territorial divisions of the country, and at the same time centrally subdivided between the urban and rural distributive systems. "Regulated goods" are subdivided within each republic between the republican torg and cooperative systems. The purchase and sale of "unplanned goods", consisting mainly of luxuries and the products of local enterprises consumed locally, is carried on by producers and retailers independent of distribution plans.

\section{Planning of contracts. ${ }^{35}$}

An essential part of the process of distribution in the Soviet Union is the planning of contracts. In this phase of the distributive system the trend toward operative decentralization is most apparent.

A general supervision over the conclusion of contracts is exercised by the Council of Ministers which annually lays down basic rules for the making of contracts for the following year. These rules set time limits for the conclusion of annual contracts in various sectors of the econoiny and establish the methods and limits of control exercised by ministries and glavki over the making of contracts by their subordinate enterprises. The Council of Ministers also exercises a review power over the decisions of the State Board of Arbitration, which has jurisdiction over contract disputes between enterprises belonging to different ministries.

In correspondence with general directives of the Council of Ministers, the various ministries give more specific instructions to subordinate business organizations regarding the conclusion of contracts for the coming year. These instructions are usually formulated as annual orders concerning the method and times for the conclusion of contracts, and the kinds of terms they should include.

The last stage of formulation of plans for the conclusion of con-

${ }^{35}$ Ibid. at 88 et seq.; Shkundin, General Contracts and Basic Conditions of Supply of Goods, ARbitrazE [1938] No. 1 (in Russian) 4; Shkundin and Grave, The Contract of Purchase-Sale in Socialized Commerce I, ArbtrrazH [1938] No. 13-14 (in Russian) .23; II, No. 15-16 (in Russian) 27; ALL-Umon INSTTTUTE of JuRWICAL Sctence, 2 CiviL LAw (1938) (in Russian) 84 et seq. 
tracts is reached when the supplier and consumer ministries or glavki and the cooperative systems draw up annual agreements regulating the flow of goods between them. These agreements are called Basic Conditions of Supply. They provide the foundation upon which socalled Direct Contracts between the immediate producing and trading or consuming enterprises are based.

Prior to 1936, instead of drawing up Basic Conditions of Supply, the higher economic organs entered into so-called General Contracts, in execution of which the "low links" (factories, plants, state farms, artels, retail shops, local consumers' unions, village cooperatives, etc.) concluded Local Contracts with each other. The General Contract determined which of the subordinate enterprises should conclude Local Contracts with each other and fixed the most important terms of those contracts. Before receiving a copy of the General Contract, the parties could not conclude a Local Contract. Whether either of these types of transaction could properly be called a contract is doubtful.

By 1936 it was felt that "the excessive regimentation by the General Contract of the terms of Local Contracts limited the initiative and independence of the middle and low links." Particularly, General Contracts proved useless as a basis for short-term contracts, single (spot) agreements, or commercial orders-transactions which were rapidly gaining importance as enterprises were put on a basis of business accountability. To correct the evils of General Contracts the Council of Ministers declared that Direct Contracts were to be concluded by low and middle links of economic systems and were to comprise the basic form of contractual relationships. ${ }^{38}$

The necessity for supervision and integration, however, remained. In 1936 and 1937, General Contracts were greatly restricted in number and in scope, though not entirely abandoned, and various sub-

38 "The Council of People's Commissars of the U.S.S.R. takes note of the following important deficiencies in the conclusion and fulfillment of contracts in 1935: (a) the substitution, in a series of instances, for low and intermediate business organizations, of centers of economic systems, which have concluded detailed General Contracts without regard for the concrete particularities and problems of lower organizations subordinate to them; (b) the unpermissible practice of delivering goods to low orgamizations on orders of superior organs, without orders of the low organizations; (c) the unsatisfactory performance of contracts, in a series of instances .... Proceeding from this, the Council of People's Coumissars of the U.S.S.R. directs: the basic form of contracts for 1936 shall be Direct Contracts concluded predominantly by low and internnediate links of (the various) economic systems ...." Decree of the Council of People's Commissars of the U.S.S.R., On the Conclusion of Contracts for 1936, Jan. 15, 1936, Corc. Laws, U.S.S.R. (1936) No. 3, art. 27. 
stitutes were tried. In 1938, the Basic Conditions of Supply became the predominant method whereby plans of distribution were brought to the organizations which actually did the distributing. ${ }^{37}$

The Basic Conditions are a set of rules agreed upon by the higher links (glavki, chiefly) of two different industries concerning contracts of purchase and sale to be concluded and executed by their subordinate business enterprises. They prescribe in more or less general terms a basis for negotiation, i.e., under what conditions contractual sanctions may be applied and what their limits must be, under what conditions a purchaser may refuse to accept a demand for payment, what standards are to govern the quality of the goods, what methods of payment are permissible. They do not attempt to cover the variations in circumstances among the different enterprises but only regulate what is common to them all. They are not contracts, nor is it essential that they be promulgated in order that contracts by subordinate business enterprises be concluded. They are, in effect, trade regulations agreed upon by representatives of the producers and purchasers of a given type of product, binding upon such producers and purchasers, but leaving considerable scope for initiative and independence in the Direct Contracts concluded in conformity therewith. ${ }^{38}$

Except in rare instances; superior economic organs no longer enter into "contracts" which are left to subordinate enterprises to enforce; the mutual transactions of business enterprises are no longer mere reproductions of plans issued higher up. Although contracts are not permitted, in theory at least, to violate the plan, but on the contrary are conceived primarily as a means of making the plan concrete and detailed, nevertheless in the distributive system itself a line has been drawn between the plan and contracts. The principle has been established that, while higher organizations do the planning, "contractual relations should be established between the business enterprises which immediately execute the contract." 39

37 "The conclusion of contracts for the supply of goods shall be carried out on the basis of Basic Conditions of Supply of Goods agreed upon between people's commissariats of glavki of suppher and consumer organizations." Decree of the Council of People's Commissars of the U.S.S.R., On the Conchision of Contracts for 1939, \& 6, ARBITRA2E [1938] No. 24 (in Russian) 1. This provision was a recognition of the success of the Basic Conditions in the practice of 1938.

38 The Basic Conditions have been criticized as being too general and allowing too much discretion to the "low links." Cf. Privorotskii, Concerning the General Conditions of the Supply of Goods of Enterprises of the Chief Administration of Light Metals, ARBITRAzB [1.939] No. 8 (in Russian) 10.

39 Shkundin, General Contracts and Basic Condilions of Supply of Goods, ArBitrazer [1938] No. 1 (in Russian) 4, 5. 


\section{GENERAL PRINCIPLES OF SOVIET CONTRACT LAW}

The distinction between plan-relations and contract-relations in the distributive system and the increased emphasis upon the importance of the latter have compelled Soviet jurists to seek to clarify the relationship between administration and law generally. A restatement of the legal primciples underlying the adjudication of contractual disputes has been necessary.

Civil-law relations do not arise in the work of planning itself. Thus preliminary planning documents (applications presented by consumer organizations to supplier, balances and plans of supply submitted by ministries to Ekonomsoviet) are merely steps in the development of the plan and do not create contractual rights or duties. With the issuance of plans of distribution by Ekonomsoviet the work of planning is still not completed. Funds and quotas must be apportioned among subordinate consumer enterprises; production must be assigned to the various producing enterprises; Basic Conditions of Supply must be drawn up. These are administrative tasks and are regulated by instructions of planning organs; disputes arising over them are settled in the administrative process by resort to superior orgamizations. ${ }^{40}$

40 Where the plans issued by higher organs of seller and purchaser are inconsistent, no civil-law obligation arises, and the parties are bound to seek a resolution of the inconsistency in the administrative process. Kharkov Electro-Mechanics Plant v. Zakavkaz Railroad, ARBIrrazF [1939] No. 12 (in Russian) 27. Plaintiff was directed by the Chief Administration of Industrial Power (Glavenergoprom) to manufacture and deliver to defendant railroad spare parts for generators, to the value of 151,000 rubles. Glavenergoprom based this instruction on an application presented to it by the Central Administration for Procurement of the People's Commissariat of Railways. In fact the latter's application was for only 100,000 rubles' worth, and it included the needs not only of defendant but also of other railroads. Moreover, the Central Divisions of Electrification of the People's Commissariat of Railways had assigned to defendant railroad, for spare parts to generators, only 10,000 rubles. Plaintiff, without entering into a direct contract with defendant, manufactured and delivered 136,000 rubles' worth of parts, at the same time presenting a written contract for the total supply, at 151,000 rubles, for defendant's signature. Defendant corrected the amount on the contract to 10,000 rubles before signing and returning it, and, in response to plaintiff's demand, refused to return the goods delivered. Plaintiff sued for enforcement of the planned contract for 151,000 rubles. Thereafter, representatives of plaintiff and of People's Commissariat of Railways entered into an agreement to convert into scrap the extra spare parts that plaintiff had manufactured under the plans issued to it but liad not delivered. Held, the agreement to convert the superfluous spare parts into scrap was "criminally uneconomic and antistate" and slould be investigated by the superior organs of the parties; defendant railroad inust pay for what it had refused to return, but the remainder should be disposed of by contract between People's Commissariat of Railways and the People's Commissariat of Electrical Power Stations and Electrical Engineering. 
Nevertheless, the issuance of plans of distribution by Ekonomsoviet creates a civil-law obligation; the supplier ministries and glavki must sell, and "independent fundholders" must buy the products allocated by the plans. If these superior organs, or the subordinate enterprises to whom corresponding planned tasks have been issued, fail to enter into such contracts of purchase and sale, or, as more frequently happens, fail to agree as to the exact requirements of the planned task, a civil-law suit may be brought to compel the conclusion of the contract, i.e., to enforce the planned task. ${ }^{41}$ It is in these so-called "pre-contract" disputes that the administrative and judicial processes overlap. The breach of the administrative obligation to complete the work of planning, the remedy for which lies in the administrative process, involves also a breach of the civil-law duty to make and execute a valid contract, the remedy for which is a judicial one. ${ }^{42}$

\section{Adjudication of disputes between state business enterprises.}

Both pre-contract and contract disputes of a commercial nature are, with certain exceptions, adjudicated by a special system of courts called the State Board of Arbitration (Gosarbitrazh). Gosarbitrazh was established in $1931^{43}$-as part of the credit reform and the movement toward business accountability ${ }^{44}$ - to supervise contractual re-

41 Failure to conclude contracts in execution of received plans is relatively rare. If a dispute arises as to whether the contract about to be entered into, or about to be performed, conforms to the planned task set for the parties, suit may be brought by either party or Gosarbitrazh may consider the case on its own mitiative. Generally, the contract must conform to the plan; but in deciding such pre-contract disputes Gosarbitrazh also considers the fault of the parties. Shkundin, op. cit. stipra note 34, at 73, 92.

42 See cases in APPENDIx, infra. Pre-contract disputes are often concerned with attempts on the part of one or both parties to avoid liability for non-performance. The following conditions attached to contracts have been held illegal, in pre-contract disputes: the right unilaterally to decrease the amount if the suppher received orders for the same product from other enterprises, the right to be released from the obligation to dehiver if materials were not received from a third party, the right to be released if the railroad failed to supply empty cars for shipment of the goods. Isakov, On Pre-Contract Disputes under Contracts for the Supply of Industrial Goods, ARBITRAzB [1938] No. 9-10 (in Russian) $35,38$.

43 Decree of May 3, 1931, CoLL. Laws, U.S.S.R. (1931) No. 26, art. 203. This law, with a few changes, is still in effect.

44 Cf. Decree of March 20, 1931, On Changes in the System of Credit, the Strengthening of the Credit Reform, and the Sectring of Business Accoutntability, Coxc. Laws, U.S.S.R. (1931) No. 18, art. 166, which provided that "all disputes arising between economic organs and involving the material liability of one of them to the other, shall be decided by organs of state arbitration" $(\$ 8)$. 
lations and adjudicate property disputes between units belonging to different commissariats (ministries), cooperative systems, etc. Disputes arising withm a single ministry or cooperative system are decided by Departmental Boards of Arbitration. ${ }^{45}$

Despite the name, the various organs of Gosarbitrazh have little in common with arbitration boards. They are, rather, "economic courts", whose jurisdiction is independent of the will of the parties, whose procedure, though informal by American standards, is similar to that of the regular courts, and whose decisions are governed by the Civil Code and by relevant statutes. A record is kept of the proceedings, and an opinion is generally written.

Though maintaining judicial standards and subordinate to civil law, Gosarbitrazh is nevertheless completely separate from the regular system of courts and is closely limked with the administrative branch of the government. Thus each of the organs of Gosarbitrazh is immediately subordinate to the supreme administrative body of the territory in which it operates, i.e., the Council of Ministers of the U.S.S.R., the Councils of Ministers of the various union and autonomous republics, and the Central Executive Committees of the local regions and districts. The administrative body appoints the members of the Gosarbitrazh subordinate to it, supervises its activities, and has power to reverse or modify its decisions or remand for retrial. ${ }^{46}$ The chief arbiter also may review decisions of other arbiters. ${ }^{4 \pi}$ This supervisory and review power is entirely discretionary; there is, technically, no appeal from the decision of an organ of Gosarbitrazh. ${ }^{48}$ Uniformity is maintained, however, by the Gosarbitrazh of the Council of Ministers of the U.S.S.R., which may on its own motion remove

45 Established by Decree of April 26, 1935. CoLx. LAws, R.S.F.S.R. (1935) No. 13, art. 136. Cases may be removed from departmental Arbitrazh to Gosarbitrazh with the permission of the responsible ministry. Also excluded from the jurisdiction of Gosarbitrazlt are: disputes to which Gosbank is a party, disputes arising from contracts of rail or water transport, disputes concerning taxes, disputes arising from contracts for public services, disputes involving less than 1000 rubles, disputes to which a collective farm is a party. Also Gosarbitrazh does not have jurisdiction over questions which are purely administrative and are within the competence of an adininistrative organ (such as questions involving the fixing of prices). MozHEIko and SHKUNDIN, ARBitrazH IN THE Sovier Econosry (2d ed. 1938) (in Russian) 30 et seq. Cf. Hazard, Soviet Commercial Arbitration (1939) 3 ARBITRATION JOURNAI 148, 150.

46 Decree of May 3, 1931, supra note 43, §§ 4, 12.

47 Ibid. $\$ 12$. In 1936, 18.4 per cent of all decisions were reviewed; 27.7 per cent of these "appeals" were successful. MozHEIKo and SHKuNDIN, op. cit. supra note 45, at 80.

48 Decree of May 3, 1931, supra note $43, \S 10$. 
cases from the lower organs to its own jurisdiction. This power is again discretionary. ${ }^{49}$

Jurisdiction as between the various levels of Gosarbitrazh is based on the amount in controversy, and diversity of citizenship or sphere of activity of the parties, i.e., whether they are enterprises of national, republican, or regional or local significance. ${ }^{50}$ Territorial jurisdiction is determined, in certain classes of disputes, by the place where the goods were received; in other classes, by the place where the property is located; and in all other classes, by the place of residence of the defendant..$^{51}$

A case may be brought before Gosarbitrazh in any one of four ways: (a) at the suggestion of the appropriate Council of Ministers or Executive Committee; (b) on commission of a superior organ of Gosarbitrazh; (c) at its own initiative; (d) at the suit of an interested party. Of these methods, the fourth is by far the most prevalent. . $^{2}$

A case brought before Gosarbitrazh is assigned by the chief arbiter to one of the permanent staff of arbiters for decision. Disputes of organizations in one or several spheres of the national economy are generally assigned to the same arbiter. Prior to the hearing the ar-

49 The chief arbiter of Gosarbitrazh of the Council of Ministers of the U.S.S.R. also convokes periodical consultations of all organs of Gosarbitrazh for joint discussion of questions of arbitrazh practice and for the establishunent of uniformity. Mozazuko and SHKUNDIN, op. cit. supra note 45 , at 23 . Impartant also in this respect is the biweekly journal of Gosarbitrazh, called ARBITRAzH, whicb publishes reports of cases, instructions of the chief arbiter, relevant new statutes, and articles on various aspects of law.

50 The Gosarbitrazh of the Council of Ministers of the U.S.S.R. has jurisdiction where the amount in controversy is 50,000 rubles or more, and where each party has its place of business in a different Union Republic or where one of the parties ranks as an enterprise of all-union importance; the Gosarbitrazh of a Union Republican Council of Ministers has jurisdiction where the anount in controversy is 25,000 rubles or more, and where each party has its place of business in a different region or territory of the Repuhlic or where one of the parties ranks as an enterprise of republican importance; the Gosarbitrazh of the Central Executive Committee of a region or territory has jurisdiction where the amount in controversy is under 25,000 rubles. Decree of May 3, 1931, sitpra note 43, $\S 4$, as amended by decision of March 4, 1938, CorL. Decisions AND Orders, U.S.S.R. (1938) No. 8, art. 52.

51 Cf. All-Union Instrtute of Jurmical Science, Civil Procedure (1940) (in Russian) 325. In the statute on Gosarbitrazh of the R.S.F.S.R. it is provided that the local organs of Gosarbitrazh of the R.S.F.S.R. may decide disputes both according to the place of business of defendant and according to the place previously agreed upon by the parties. Corr. Laws, R.S.F.S.R. (1933) No. 35, art. 127, note to $\$ 8$.

52 All-Union InstTTUTe etc., op. cit. supra note 51, at 326. The first three methods are important chiefly in pre-contract disputes. 
biter makes a preliminary preparation of the case..$^{53}$ This preparation may include: (a) a study of the materials presented by the parties and of supplementary materials (documents, accounts, entries) received from them at the request of the arbiter; (b) examination of documents of other organizations and institutions, if such documents are necessary for the decision of the case; (c) summons of officials of the disputing parties for preliminary explanation of any circumstances; (d) a view by the arbiter of the object of the dispute or the setting in which it arose; (e) joining of other organizations as participants in the case; ( $f$ ) investigation of questions not raised by the parties, if they appear to be relevant; (g) appointment of experts, if the disputed question requires the conclusions of competent specialists.

The case is tried informally before the arbiter. The directors of the contestants may be present or may delegate others to represent them. ${ }^{54}$ The procedure is governed by the general principles of the Code of Civil Procedure. The arbiter is master of the court; he interrogates the parties and comes to their aid, so that no advantage may result from inadequate knowledge of the law, illiteracy, or similar handicaps. ${ }^{65}$

In rendering his decision, the arbiter has very broad powers. ${ }^{56}$ He may decide the case on an entirely different basis than that argued by the parties. He may exact damages from both plaintiff and defendant. He may give judgment beyond the claims or counterclaims of either party. He may, and generally does, order specific performance. Moreover, in cases of repeated breach of contract he may award penalty damages. He also has the power and the duty to report

\section{Ibid. at 329.}

of Cf. Hazard, op. cit. supra note 45 , at 152 . Of the cases decided by the All-Union Gosarbitrazh in 1938, in only thirty-nine per cent were the directors of both parties present. The Work of Gosarbitrazh of the Council of People's Commissars of the U.S.S.R. for 1938, ARBITRAZH [1939] No. 4 (in Russian) 2. More and more, directors of enterprises are substituting their legal advisors in cases before Gosarbitrazh. This practice, once frowned on, is now accepted. Where the facts are not in dispute, the directors need not be summoned.

55 "The court ... . Inust, by interrogating the parties, contribute to a clarification of the facts relevant to the decision of the case ... so that no advantage may be taken of inadequate knowledge of law, illiteracy, or similar circumstances." CODE of Crve ProCEDURE, R.S.F.S.R., art. 5. In the official commentary to this provision, it is stated that the court has a duty to help the parties during the course of the proceedings.

50 Mozmetro and ShKundin, op. cit. supra note 45, at 94 et seq. Cf. cases in Apren$\mathrm{DIx}$, infra. 
("signalize") harmful practices to the responsible ministry, or, if criminal activity is involved, to the state prosecutor.

Nevertheless, despite this large grant of powers, Gosarbitrazh is bound by law. ${ }^{57}$ The theory which formerly prevailed that civil-law contracts are to be restricted to that sector of the national economy not directly subject to planning is vigorously denounced. ${ }^{\text {ss }}$ The importance of planning is in no way minimized; on the contrary, it is stated unequivocally that every dispute between state business enterprises must be decided in the general interests of the state, i.e., in the direction of realizing the planned tasks set by the state. But the subordination of Gosarbitrazh to civil law, the necessity for procedural correctness, ${ }^{59}$ and the protection of the legal rights and interests of

5i Sec. 8 of the Decree of May 3, 1931, supra note 43, states: "In deciding disputes, Gosarbitrazh shall be guided by the laws and dispositions of the central and local organs of state power and also by general principles of the economic policy of the U.S.S.R." Earlier interpreted as authorizing a disregard for both law and contract, this provision is now understood differently. Cf. MozHErko and SHKunDIN, op. cit. supra note 45, at 10: "Accordingly, it is proper to reject the clearly untrue arguments of the opponents of Gosarbitrazh, that only the courts must be guided by law, but Gosarbitrazh is freed from it. It is proper definitely to condemn and to punish those arbiters who imagine that an arbitrational decision may go contrary to law because the decision not corresponding to law is 'economically convenient'. Gosarbitrazh does not have the right to depart from law even by one step. Furthermore, if Gosarbitrazh sees in a contract or in its individual terms a contradiction to law, it is obliged to bring the contract into correspondence with the law and, in proper cases, through the prosecutor to bring the persons who committed the illegality to criminal responsibility. Since not all questions arising in economic relations are regulated by law or by decree of the government, the statute (on Gosarbitrazh) indicates that in such cases the general principles of the economic policy of the U.S.S.R. are applicable. Accordingly, the arbiter must be pohitically and economically hiterate, must see that his decisions correspond to the general directives of the government. [But] may Gosarbitrazh, in deciding a dispute, depart from the terms of a legally concluded contract? No. At the same tine, departure fron contractual terms is obligatory when this is dictated by law, i.e., when the terms of the contract contradict the law .... Of course the arbiter is not bound by the literal sense of the contract in those cases when it appcars that the economic relations were in fact not such as the contract stated."

58 Cf. Amfiteatrov, On the Conception of Soviet Civil Law, Sovmer STate ANd Law [1940] No. 11 (in Russian) 94 et seq., where civil law is defined as the regulation of property relations on the basis of socialized ownership of the nueans of production. Cf. Mozmerro and SHrondn, op. cit. supra note 45, at 68, where it is stated that the placing in opposition of legality and economic expediency "is undisputedly the antiParty, anti-Marxist 'theory' of Pashukanis and his followers, who denied the socialist character of Soviet law, preaching and in fact inculcating a contemptuous attitude toward the laws of the Soviet state."

59 "In the first period of activity of Gosarbitrash, its former leadership denied the necessity of procedural norms, asserted that the activity of Gosarbitrazh was not bound 'by any procedural and other formalities' . . . , disseminated a unique 'theory' of 'procedural nihilism' ..." Mostrerko and SHKuNDIs, op. cit. supra note 45, at 25. In 1934 
the parties are now acclaimed as essential to the life of the Plan itself. It is declared:

"The defense of the interests of the state, of socialist ownership, is achieved by means of the defense of individual enterprises and organizations representing that ownership." 60

Thus, whereas economic expediency was previously hailed as the ultimate criterion for the decision of disputes, it is now stated that the law is itself the highest expediency. And particularly, Gosarbitrazh is declared to be bound by the Civil Code and the statutes supplementary to it.

\section{Contract law in the Civil Code.}

The major part of the Civil Code deals with "obligations", which are defined as legal relationships by force of which one person (or persons) has the right to demand from another person (or persons) the commission or omission of some act. ${ }^{61}$ Such obligations arise chiefly from three types of civil-law transactions: contracts, unjust enrichment, and the injuring of another. ${ }^{62}$ The implication of such a classification would seem to be that common principles will be applied to contractual, quasi-contractual, and tort controversies; indeed, in the treatment of void contracts, in the allocation of responsibility for breach of contract, and the award of damages for such breach, doctrines of unjust enrichment and of.fault are conspicuous.

A contract is defined as a mutual agreement, i.e., a mutual expression of coinciding wills of two or more subjects of law directed toward the establishment, change, or discontinuance of legal relationships. ${ }^{.3}$ The mutuality of a contract distimguishes it from a testa-

the leadership of Gosarbitrazh was changed. Circulars and orders concerning procedural questions became frequent. $C f$. BuLLETIN OF GosarbitrazH OF THE COUNCII OF PEOPLE'S Commrissars of tere U.S.S.R. [1934] No. 18 (in Russian). Cf. Shkundin, Making Precise the Rules for Hearing Arbitration Disputes, ARBITRAZH [1938] No.11-12 (in Russian) 2.

$B 0$ MOZHEIKO and SHKUNDIN, op. cit. supra note 45 , at 21 .

61 CIVIL CODE, R.S.F.S.R., art. 107.

62 Ibid. art. 106. But cf. Agarkov, The General Doctrine of Obligations, ARBITRAzE [1938] No. 15-16 (in Russian) 20, at 22, in which it is stated that art. 106 does not give an exhaustive list. Agarkov adds to those foundations from which obligations arise:

(a) acts of competent state organs in regulating and planning the national economy; (b) unilateral expressions of will (e.g., the obligation imposed by a testator on one of the heirs for the benefit of another heir); (c) obligations based on law (e.g., the obligation of parents to support their children).

03 Lipetsker and Shkundin, The General Doctrine of Contracts, ARBIrRAzH [1938] No. 23 (in Russian) 21. Cf. CIVIr CoDE, R.S.F.S.R., art. 26. 
ment or an offer in which the mind of only one person is manifested; the contemplation of legal consequences distinguishes it from a mere "friendly agreement".

Contracts may be oral or written. ${ }^{64}$ Contracts for more than 500 rubles and all contracts of sale made by state business enterprises are obliged to be written. A breach of this requirement leads to the application of what might be called a parol evidence rule: in a dispute about the existence of the contract or its contents, the parties may introduce only written proofs of such, but if the dispute relates merely to the execution of the contract then oral evidence is admissible. Certain contracts must also be notarized, and certain others must be registered. If the parties have agreed, or if the law requires, that a contract be written or notarized or registered, it is considered to have taken effect only from the time of the formal act.

The rules laid down in the Civil Code regarding offer and acceptance, novation, mistake, impossibility, etc., provide little that is unusual. ${ }^{65}$ Likewise, other types of contracts listed-such as contracts to enter into a future contract, contracts for the benefit of a third person, etc.-are similar to those of western law generally.

\section{Freedom and authority in Soviet contract law: doctrine of mullity.}

The distinctive characteristics of Soviet contract law may be understood less from definitions and classifications than from the socialist philosophy of freedom and authority that underlies them. It is recognized that the very idea of contract presupposes some freedom on the part of the parties to express their wills. Formerly challenged as a "bourgeois" fiction, to be superseded under socialism by the will of society (as manifested in Plan), such freedom of will is now upheld as a fundamental principle of Soviet contract law. ${ }^{66} \mathrm{It}$ is not considered, however, as a natural right, but rather as a right emerging from social conditions. Its source is found in the harmony of social and personal interests under socialism, and in the equality

64 See AxI-Union Instrrute etc., op. cil. supra note 35, at 41 el seq.

${ }^{65} \mathrm{Cf}$. cases in APpEndix, infra.

66 "The basic constitutive characteristic of a contract is the agreement of the parties, the coincidence of their wills, directed toward the achievement of a definite legal result. The statements of the wreckers were therefore directed toward showing the absence of the will of the parties, of their agreement, in contracts under Sovict law, primarily in planned contracts in socialist organizations. Plan and Law were placed in contradiction as irreconcilable things. These wrecking tendencies taught a contemptuoug attitude toward contract; . . . they brought great injury to our national cconomy." Lipetsker and Shkundin, op. cit. supra note 63, at 22. 
of bargaining power of the contracting parties. Actual freedom of contract, it is said, is thus created by socialism itself-by the absence of unemployment, by confidence in the future, by regulation and integration of the national economy ${ }^{67}$ Moreover, experience has shown that the welfare of the national economy itself requires the granting of imitiative and responsibility to the parties.

The polar relationship of freedom and authority, the initiative of the individual enterprise and the undivided will of society, is illustrated by the treatment of invalid contracts in Soviet law. Article 30 of the Civil Code declares invalid any contract made for a purpose contrary to law, made in evasion of the law, or directed to the clear detriment of the state. Article 147 requires that in the event a contract is invalid under article 30 , neither of the parties shall have the right to demand from the other the return of whatever has been performed; instead, it may be treated as unjust enrichment to be forfeit to the state. These articles were originally held applicable to the transactions of private citizens only; with the growth of the business accountability and juridical personality of state business enterprises, they have been applied to contracts between such enterprises. ${ }^{\text {es }} \mathrm{Par}$ ticularly, a contract in violation of state planned tasks is held to fall withm the provisions of article 30 .

The application, however, of article 147 does not follow automatically from the application of article 30 . Under the latter, the intention of the parties is irrelevant; a contract within its categories is "absolutely invalid". ${ }^{69}$ But judicial practice has required for the applica-

${ }^{67}$ Ibid.

0s By an order of the Plenum of the Supreme Court of the R.S.F.S.R. of May 16, 1927, it was declared that arts. 30 and 147 of the Civil Code were applicable to contracts between private citizens only. This order was explicitly overruled by an order of the Plenum of the Supreme Court of the U.S.S.R. of July 16, 1939, which declared that the 1927 order "contradicts the tasks of the strengthening of Socialist legality and of business accountahility in the relationships of institutions and enterprises." The 1939 order had been preceded by several cases in which the organs of Gosarbitrazh had applied arts. 30 and 147 to contracts hetween state business enterprises. Novitskii, op. cit. infro note 69, at 42. Cf. Z. I, Questions of the Applicability of Article 147 of the Civil Code to Relations Between State Organs, ARBITRAzH [1938] No. 3 (in Russian) 15.

69 See Novitskii, Invalid Agreements, Acadeary of Scrence of teE U.S.S.R., QuesTIONS OF SOVIET Crvil LAW (1945) 31. In this extremely learned and intelligent article, the author discusses the development of the concepts of void and voidable contracts in legal history and in the various European (including the English) legal systems, arriving at the conclusion that " $a$ contract void for $A$ and at the same time valid for $\mathbf{B}$ is nonsense". Since the Soviet Civil Code and Soviet legislation do not use the word "voidable" but speak only of valid and invalid (literally, effective, and ineffective) contracts, Novitskii proposes the following classification: (1) valid contracts, (2) non-existing con- 
tion of the penalty of article 147 the presence of a subjective intent. The detriment to the state must have been apparent at the time the contract was made; the parties must have acted in bad faith. Further, the court may or may not apply article 147 at its discretion; restitution may be granted to an innocent party. ${ }^{70}$

A contract not absolutely invalid for illegality may be "relatively invalid" for fraud or impossibility. ${ }^{71}$ Here also the element of fault, previously rejected by Soviet jurisprudence as a criterion for decisions in both contract and tort law, has become increasingly important. $^{\tau^{2}}$ Where there is fraud, the innocent party has the right to restitution of everything which he has performed under the contract, but any profit is forfeit to the state. ${ }^{73}$ In the case of impossibility of performance due to circumstances which could not have been avoided by the obligor or which were caused by the fault of the obligee, the obligor (in the absence of a contrary provision by law or by contract) is freed from responsibility under the contract. A contract made by one lacking in civil capacity, either by virtue of insanity or infancy, is also "relatively invalid"; each party is required to return everything received under the contract. ${ }^{74}$

The Civil Code also provides for annulment by the court of any legal transaction concluded by a person under duress to his clear detriment. ${ }^{75}$ Such contracts and transactions are not merely "voidable" at the suit of the protected party; they are ineffective ( $a b$ initio) to accomplish their purpose, and they give rise to the obligation to restore the parties to their original position. Such contracts and transactions may be attacked on the initiative of the state prosecutor,

tracts, (3) incomplete contracts, (4) invalid contracts, and, under (4), [a] absolutely invalid and $[\mathrm{b}]$ relatively invalid contracts.

70 See Cases 6, 7, 8, 9, 10, 11 in Appendix, infra.

71 CIVIL Code, R.S.F.S.R., arts. $32,118$.

72 "All who lave been interested in questions of Soviet civil law remember that for a long time the view prevailed among us that liability from the point of view of the Civil Code is objective liability, i.e., that it does not presuppose fault but arises from causation alone. This theory served to explain botls contractual and non-contractual liability. In regard to non-contractual liability, it found expression in our literature for a long time, but in recent years it has finally lost ground. At the present time the vicw prevails that liability under art. 403 (on torts) is based on fault." Agarkov, On the Question of Contractual Responsibility, ACADEMX OF SCTENCES OF THE U.S.S.R., QUESTIONS of SOVIET Crvm LAW, (1945) (in Russian) 114, 121. The author shows the revival of doctrines of fault in contract law. $C f$. also the corresponding changes in criminal law, cited in Principles of Soviat Criminal Law, supra note 2.

73 CIVI Code, R.S.F.S.R., art. 149; CASE 10 in Appendrx, infra.

74. Ibid. arts. 31, 148.

T5 Ibid. art. 33. 
independently of the will of the parties immediately interested but in their behalf and in behalf of the public interest. ${ }^{76}$

\section{CONTRACTS OF PURCHASE AND SALE BETWEEN STATE BUSINESS ENTERPRISES}

Contracts of purchase and sale between Soviet state business enterprises bear a double aspect. On the one hand, they are a means of fulfillment of the Plan; on the other, they serve to establish relationships of law. The Plan sets limits to the terms which may be included in contracts. It governs, broadly or narrowly, such questions as: what kinds of enterprises shall buy and sell what kinds of goods; how much shall be bought and sold during the year; what prices shall be paid. The law defines the rights and duties that arise from transactions entered into. It governs such questions as: whether the contract violates the Plan or the Civil Code or any other law of the state; whether the acts of the parties conform to their agreement; what remedies may be granted to an injured party, or to the state, for failure to conform to the law or to the contract.

The Civil Code provides a set of general principles by which contracts of purchase and sale are tested should disputes concerning them arise in Gosarbitrazh. These principles are similar to the AngloAmerican law of sales. ${ }^{77}$

Perhaps the most distinctive feature of the Soviet law is the right which it gives to either the purchaser or the seller, upon breach by the other party, to demand specific performance of the contract as well as damages caused by the breach. ${ }^{78}$ Although the Civil Code also

70 Berman, loc. cit. sulpra note 2.

77 The seller undertakes to transfer property to the purchaser, and the purchaser undertakes to accept such property and to pay the stipulated price. In the case of fungible goods, the right of ownership passes at the moment of their delivery; in the case of non-fungible goods, at the moment of completion of the contract. Unless otherwise provided by contract, the risk of accidental destruction or deterioration of the property sold passes to the purchaser simultaneously with the passage to him of the right of ownership; however, if either party is responsible for delay in the delivery of the goods, the risk of accidental destruction or deterioration is borne by that party. Where the same product has been sold to several persons, ownership under Soviet law is in the purchaser with whom the contract of sale of the product was first concluded; if it is impossible to determine who was the first purchaser, the one to whom the product. was delivered is the owner; but if a suit for delivery of the product is brought by one of the purchasers before delivery of it to any of them, the one who first brings suit is deemed to be the owner. Civit Code, R.S.F.S.R., arts. 66, 180, 186, 191 ; AII-UnIon INSTIrute etc., op. cit. supra note 35 , at 66 .

is CIVII CODE, R.S.F.S.R., arts. 189, 190. "In the event of nonperformance by the obligor of his ohligation, he is obliged to compensate the creditor for the losses caused 
gives the injured party the alternative of rejecting performance and suing for damages alone, the practice of Gosarbitrazh has been to award specific performance where to do so would accord with the plans of distribution issued for the parties.

\section{The terms of a contract of purchase and sale..$^{\text {i9 }}$}

Contracts of purchase and sale between state business enterprises must be in writing ${ }^{80}$ and must contain the following terms: ${ }^{81}(1)$ the names of the parties, (2) a description of the goods and an exact statement of their quantity, (3) the times for deliveries, (4) a statement of the quality of the goods and, in proper cases, of their assortment and the complete parts, (5) the price, (6) the terms of payment, and $(7)$ the guarantees of performance. In annual contracts other terms are also generally included, concerning the place and method of delivery, the freightage, packing, and so forth.

\section{The parties.}

With the issuance of plans of distribution by Ekonomsoviet, the parties who are to buy and sell given products are usually established by decrees of the government or by order of the various ministries. In some cases only the supplier and consumer glavki or even ministries are so established, and the enterprises within such glavki or ministries are to that extent free to choose with whom they will deal. The choice of buyer and seller is left entirely to the parties in the purchase and sale of unplanned goods ${ }^{82}$ in the execution of so-called

by nonperformance. By losses shall be understood both positive damage to property and unrealized profits obtainable under ordinary conditions of trade." Ibid. art. 117.

${ }^{79}$ See Shkundin and Grave, The Contract of Purchase-Sale in Socialized Commerce I, Arbitrazir [1938] No. 13-14 (in Russian) 23; II, Arbitrazh [1938] No. 15-16 (in Russian) 27. Cf. ALI-UNION INSTITUTE etc., op. cit. supra note 35, at 81 et seq.

80 Decree of Feb. 18, 1931, CoLr. LAws. U.S.S.R. (1931) No. 10, art. 109. Contrast Crvin Cone, R.S.F.S.R., art. 136, which requires only that contracts for more than 500 rubles be in writing.

81 Decree of Dec. 19, 1933, Coll. Laws, U.S.S.R. (1933) No. 73, art. 445. This list is not absolutely mandatory, i.e., the court may supply missing terms. The principle is established that the contract "must he concrete, operative, and exact." Shkundin and Grave, op. cit. supra note 79, I, at 30. See CASEs 12, 13, 14 in Appendrx, infra.

82 If an enterprise purchases unplanned products beyond its planned needs, the contract is nonetheless valid, though it may be modified in the administrative process at the discretion of Ekonomsoviet, the Council of Ministers of the U.S.S.R., the Council of Ministers of the appropriate Union Republic, etc. Shkundin, op. cit. stipra note 34, at 84,93 . 
single contracts (spot sales), ${ }^{83}$ and in the execution of contracts through state bureaus of commercial mediation (Gostorgposredkontory) to which enterprises may resort voluntarily for the negotiation of contracts in intra-regional and inter-regional trade. ${ }^{84}$

The quantity of the goods.

The Soviet Constitution places a limitation on what goods may be purchased and sold by declarmg certain kinds of property to be res extra commercium. These goods include the land, its natural deposits, waters, forests, railroads, business enterprises of all kinds, buildings, and others. ${ }^{85}$ The attempt to sell parts of a plant or its equipment in the guise of superfiuous materials is a criminal offense. A further limitation on the goods that may be sold is the plan itself, which prescribes that certain types of goods shall be bought and sold by certain types of enterprises; a contract which violates the plamed tasks set for the parties may be declared invalid.

Where plans of distribution are issued annually or quarterly, the quantity of goods sold and purchased annually or quarterly must correspond to such plans. Within the year or the quarter, the quantities are fixed by the parties. In disputes over quantity, Gosarbitrazh proceeds generally on the basis of the primacy of plan over contract, but also it considers the fault of either of the parties.

\section{The time.}

Since plans are issued annually, most business enterprises know at the beginning of the year what goods they will have to buy or sell during the year in order to fulfill their part of the plans. As a result, annual contracts are generally concluded even where they are not obligatory. Contracts for more than a year may also be concluded. All contracts are also required, however, to state the so-called partial

83 Single agreements, i.e., contracts providing for a single release of goods are entered into chiefly for goods in wide demand, where the seller is a wholesale base and the purchaser a torg, retail shop, regional consumers' cooperative association, village cooperative society, etc. Also they are used for the purchase of dismantled and superfiuous equipment by organizations specially created for rebuilding such equipment. Shkundin and Grave, op. cit. supra note 79, I, at 30 .

84 These bureaus, or stores, were established by Decree of May 4, 1936 (Cour. Laws, U.S.S.R. [1936] No. 801) "to expose the supply and demand of goods, to mediate in the purchase and sale of goods by business enterprises which have voluntarily resorted to them, for the purpose of maximun extension of intra-regional and inter-regional commerce under conditions of strict observance of established prices." The freedom they are given is solnetimes abused. See CASE 9 in ApPENDIx, infra.

85 U.S.S.R. Const., Art. 6. 
times of execution, i.e., the times in which the parties are obliged to fulfill exactly defined parts of the obligations of the contract. In certain contracts there may be exact graphs for delivery of goods by days and even by hours (for example, in contracts between bakeries and bread shops).

In the event of a breach by the seller of the times of execution stated in the contract, the purchaser has the right to refuse to accept the delayed goods. However, he is obliged to inform the seller of such refusal, unless a term regarding the refusal of delayed goods is contained in the contract, in each separate instance of delay; if the goods are shipped by the supplier before receipt of such information, the purchaser is obliged to accept them.

\section{Quality, assortment, completeness. ${ }^{86}$}

The quality of goods to be supplied under a contract may be fixed in one or all of three ways: (1) by reliance on all-union standards issued by the Council of Ministers of the U.S.S.R. or by individual mimistries thereof, (2) by a description of the goods in the written contract, or (3) by reliance on samples. Generally the place for examination of the goods for defects in quality is determined by the contract or by the rules of the particular trade; in the absence of these provisions, examination is made in the case of inter-city trade at the warehouse of the purchaser, and in the case of intra-city trade at the warehouse of the seller. Strict time limits are imposed for such examination; by contract they may be reduced. Hidden defects may. serve as a basis for claims made within five days after their disclosure but not later than three months after the delivery of the goods.

Goods may also be delivered on certificates of the State Board of Inspection for Quality, in which case the purchaser is obliged to examine them only when he has reason to doubt the correctness of the certificate or when the quality of the goods was subject to change during transit.

Where the goods are of bad quality and cannot be used for the purpose for which they were bought, the purchaser has the right to return them, except for perishables, to the seller, and to receive the proper goods in their stead in addition to a penalty of ten per cent

86 Cf. Decree of Aug. 29, 1939, On Method and Times of Presentation of Clains by One State Business, Cooperative, or Social Organization to Another for Supply of Good's of Improper Quality, ARbitrazH [1938] No. 17-18 (in Russian) 3. See CASES 15, 16, 17,18 in APPENDEx, infra. 
of their price (unless the penalty is fixed otherwise by contract). He may accept the goods at a lower price, which may be determined by the fixed current price, the official standard, the agreement of the parties, or the conclusions of an expert; the purchaser may correct the defects at the expense of the seller; he may demand correction of the defects by the seller; he may refuse to accept the goods. Any devaluation in price must be carried over to the consumer when goods are subject to resale.

Before making a claim on the ground of defects im the quality of the goods, the purchaser must summon a representative of the seller to participate in the drawing up of a report; if the purchaser and seller are located in different places, and in the place of residence of the purchaser there is an enterprise subordinate to the same glavk as that of the seller, or which sells the same goods, the purchaser must summon a representative of that enterprise instead.

Suit may be brought, if there is a dispute over liability or damages, in Gosarbitrazh at the place of the receipt of the goods. Gosarbitrazh is obliged, on request of either party, to join as defendant the manufacturer or carrier, though not a party to the contract, in order to eliminate the necessity of further so-called regressive suits.

Expert testimony is naturally of great weight in suits of this type. The parties may call their own expert witnesses, and the court, in case of doubt, is obliged to summon its own experts, generally selected from the State Board of Experts. ${ }^{87}$ The court may order all the experts to make a joint investigation. ${ }^{88}$ Damages are usually estimated in terms of penalties fixed by contract or by law, and based on a percentage of the wholesale or of the cost price.

The correlations (expressed either in percentages or in sizes) of kinds, forms, measures, fashions, colors, weights, etc., of goods are

87 "The importance of the State Board of Experts lies not only in their role in establishing the quality of goods in individual instances for the purpose of deciding concrete disputes between sellers and buyers.... [but also] Actively to participate in the struggle for the high quality of goods, carefully to expose the causes for deterioration of goods and to help business organizations eliminate those causes, to render constant aid to state organs in the struggle against malicious waste-lierein lies the basic task of the organs of the State Board of Experts." Shub, The State Board of Experts and the Struggle for Quality in Production, ARBITRAzB [1939] No. 11 (in Russian) 9. Cf. recommendation of Gosarbitrazh of the Council of Ministers of U.S.S.R. that quarterly or semi-annually it (Gosarbitrazh) have a conference with the State Board of Experts and other interested economic organs in order to discuss their work in terms of the struggle against the sale of products of bad quality. Instructive Letter of Gosarbitrazh of Council of Ministers of U.S.S.R., ARBITRAZE [1939] No. 17-18 (in Russian) 6.

88 See CASE 18 in APPENDIX, infra. 
called the assortment of the goods. The assortment is established in the contract or else in preliminary orders issued by wholesalers which are deemed to be part of the final contract. If a penalty clause concerning breach of assortment is not contained in the contract, a penalty of three per cent of the cost of the goods for improper assortment is assessed. ${ }^{59}$

The seller of complex products such as machines with instruments and devices is required to deliver them complete and in working order, and he is not relieved of this obligation by the fact that individual parts are manufactured by other enterprises, nor can he be relieved of it by contract. If the penalty for incompleteness is not provided in the contract, then it is assessed at 100 per cent of the cost of the unsupplied parts, subject to an increase of twenty per cent of the prices of all products unable to be used as a result. In cases of repeated and systematic breach of provisions regarding quality, assortment, and completeness, Gosarbitrazh may increase the penalty beyond that fixed by contract or by law.

\section{The price. ${ }^{00}$}

The Constitution authorizes all prices to be fixed by the Council of Ministers of the U.S.S.R., ${ }^{91}$ which issues directives and instructions in this regard to the various ministers, to the councils of ministers of union republics and autonomous republics, and to the executive committees of regions and districts. Prices of industrial goods are fixed on the basis of commercial cost (which includes all expenses involved in producing the goods), planned profits, and turnover tax, as well as the cost of delivery. Prices of consumption goods are fixed on the same basis plus additional marketing costs and profits. Prices may be fixed for given products sold by particular branches of industry, or current prices may be issued for classes of products. Prices in contracts must correspond to official prices exactly; the contract must state the price definitely, and where it is provided in the contract that the current price will be relied upon, the date of the issuance of the current price must be stated.

89 "An insignificant departure from the stipulated assortment may not serve as a basis for refusal by purchaser to receive all the goods delivered." Chief Administration for Perfumes v. Ershovskii Regional Consumers' Union, ARBrTRazH [1938] No. 2 (in Russian) 27.

90 Goloshchekin, Dispntes over Accounts, Arising from the Application of Contractual Prices, ArbTtrazH [1938] No. 24 (in Russian) 5; Rabinovich, Disputes over Price for Goods of Mass-Consumption, Arbitrazh [1938] No. 8 (in Russian) 14.

91 U.S.S.R. Const., Art. 68(b). 
Despite these regulations, nine per cent, or more than 30,000 , of the cases considered by Gosarbitrazh in 1938 were disputes over prices. ${ }^{92}$ Some such disputes involve a breach of official prices, sometimes open and sometimes concealed. ${ }^{93}$ Others arise where the goods are released on a large scale for the first time and hence no price has been issued for them; the parties in such instances have the right to establish a temporary price with a provision for re-accounting on issuance of the official price. Disputes over re-accounting occur also when there are changes in previously prevailing prices, or when the parties are authorized to establish preliminary prices subject to a re-accounting. The problem is further complicated by the presence of various factors other than the price fixed by the government or the current price. Thus commercial price increases, regulated by law, may be added to the official price of retail goods; prices vary in different zones of the U.S.S.R.; bonuses may be paid by the seller to the buyer, which are in effect a reduction in price; increases and decreases are permitted for variations in the quality of the goods; a twenty per cent price increase was authorized in 1938 on products of local industry sold locally; transportation costs, normally determined as part of the price, may be the subject of controversy.

The role of Gosarbitrazh in considering disputes over price is to enforce the government's price policy, on the one hand, without usurping the functions of administrative bodies by actually setting the price, on the other. In walking this narrow line, Gosarbitrazh is often required to deal with complex questions both of contract and of administrative law. Where the goods are not officially priced, an analysis of the elements of price formation in manufacturing operations may be required in order to determine the relation between the price agreed upon by the parties and the actual cost of production. Since prices of mass-consumption goods differ from prices of industrial goods, questions arise as to whether particular goods are in mass consumption or in industry. In deciding such questions, Gosarbitrazh often calls in representatives of the industrial ministry involved to give expert testimony on the application of current prices.

92 See Cases 2, 20, 21 in Appendix, infra.

03 Examples of attempts to conceal breach of established prices are: use of larger jars for conserves, where the current price was established per kilogram; charging for extra parts, where the goods were sold as a whole; charging for transportation costs although such were included in the prices issued; not offering purchaser exemptions and reductions provided by law; etc. Shneerov, The Establishment of Prices and Disputes over Prices in the Practice of Gosarbitrazh, ARBITRAzE [1933] No. 20 (in Russian) 9. 
Gosarbitrazh may hold that the proper remedy is in the administrative organs responsible for issuing prices for a given product. Where the current price has been modified on the ground that the quality of the goods is higher or lower than that provided in the contract, Gosarbitrazh considers the suit as one for damages caused by breach of the terms of the contract and determines the measure of damages as the difference in price. In deciding the proper price for goods manufactured under one set of prices but delivered after the introduction of another set of prices, Gosarbitrazh has held that the proper price is the one which existed at the moment of the transfer of the right of ownership to the goods.

In general, where the contractual price is improper, Gosarbitrazh merely orders the parties to re-account. Where there are systematic errors of this kind in the case of a particular enterprise, Gosarbitrazh reports the dispute to superior adninistrative bodies. Where there is a conscious breach of established prices, the officials responsible for it are subject to punishment for an official crime. Other remedies which may be applied by Gosarbitrazh are the award of damages and the application of article 147 of the Civil Code, which requires the forfeiture of whatever has been performed under the contract.

Terms of payment.

Since 1930, all purchases of over 1000 rubles must be nuade on credit, ${ }^{9 \neq}$ and all credit transactions between state business enterprises must be carried on through Gosbank; since 1936, Gosbank has extended credit on the basis of strict business accountability of the business enterprises. Payment may be made in one of a variety of ways, including: (1) acceptances, (2) letters of credit, (3) transfers, (4) commissions of payment, (5) checks, and (6) planned payments.

(1) The acceptance. ${ }^{95}$ The predominant method for the payment for goods or for services is by the payor's acceptance, through his bank, of the payee's demand for payment presented through his bank. The seller, having shipped the goods (or rendered the services), presents a demand for payment, in triplicate, to his bank for collection,

94 Up to ten rubles, accounts must be carried on in person. Gosbank may increase this sum to 500 rubles. Also, accounts up to 1000 rubles may be carried on in person. Below 100 rubles, accounts mutst be paid in cash; from 100 to 1000 rubles, checks or commissions of payment may be used. Kamenskii, Intra-City Accounts, Arbitrazar [1938] No. 1 (in Russian) 19.

95 See Kamenskii, The Acceptance Form of Extra-City Accounts, Arbirrazk [1938] No. 21 (in Russian) 14. 
together with triplicate copies of whatever documents are called for by the contract (invoice, bill of lading, voucher, etc.). The seller's bank forwards two copies of the documents and of the demand for payment to the buyer's bank, which notifies the buyer of their arrival and, unless he refuses to accept the demand within three days, deducts the sum to be paid from his account and transfers it to the seller's bank. If, however, there are not sufficient funds in the buyer's account on the day on which payment is to be made, the bank notifies the seller's bank, which notifies the seller, of the failure to pay. A penalty is exacted from a payor who lacks sufficient funds.

In general, the payor has the right to refuse acceptance in all cases provided by law or by contract. He must, however, in notifying his bank of such refusal, set forth the grounds therefor, indicating the law or the clause of the contract on which he relies, as well as the character of the alleged violation or breach. The bank's function is to verify whether the grounds of refusal are valid on their face. It is limited in its control over the refusal by the nature of the operation which is based on the acceptance of documents and not of goods. Thus a refusal on the ground of nondelivery of the goods will be rejected by the bank; nor will the alleged defective quality of the goods serve as a basis for refusal unless they have arrived before the expiration of the time for acceptance and the buyer therefore had the opportunity to verify their quality. Further, since the payor has not the right to refuse in full where a partial acceptance is possible, his bank will not take up a full refusal if he has based it on grounds which justify only a partial refusal. The substantive legality of the refusal, however, is a question to be decided by Gosarbitrazh on the suit of either party. ${ }^{96}$

Ordinarily, the buyer is responsible for storage of the goods delivered to him, even though he refuses to accept the demand for payment. In the case of perishable goods the buyer who refuses acceptance is obliged to take all necessary measures to prevent their ruin, including the selling of the goods for the account of the seller. Also Gosbank may impose the duty of storage and safekeeping of goods upon a buyer which has systematically failed to pay its obligations.

96 "The mutual relations under the demand for payment in no way shield the real relations under the shipment of the goods .... The acceptance form of accounts is based on the acceptance of the demand for payment and not of the goods. This means that purchaser carries out his duties under the acceptance . . . independently of whether or not he received the goods. He may always resort to the court or to Arbitrazh." Shvartsman, Extra-City Accounts, ARBITRAzE [1939] No. 3 (in Russian) 16. 
Where an enterprise is entirely deprived of credit facilities by the bank, the bank itself, at the seller's request, is obliged to take the responsibility of storage. Thus the bank derives control over the goods which are situated in the warehouse of the buyer, the buyer being obliged to present to the bank all documents necessary for such control. The seller may instruct the bank to ship or to sell the goods, in which case the bank issues corresponding instructions to the original buyer. If the bank sells the goods, it requires payment in advance, and transfers the money to the original seller only when it is convinced that the original buyer has delivered the goods. All claims connected with the sale of the goods by the bank must be brought against the seller and not against the bank.

(2) Letters of credit. ${ }^{97}$ Next to the acceptance in importance as a method of keeping accounts in the purchase and sale of goods by state business enterprises is the letter of credit. Generally, where a letter of credit is placed with the seller's bank by the buyer's bank, at the commission of the buyer, the seller has merely to present the bill of lading to his bank in order to be credited for the amount of the payment. The buyer may, however, require that payment shall not be made without his acceptance; he may impose supplementary conditions, such as the presentation by the seller of certificates of quality of the State Board of Inspection, or the prohibition of partial payments, or the shipment of the goods to a particular destination. In any case, a letter of credit is invalid unless it contains the name of the seller (a bearer letter of credit is not allowed), the description of the goods or services to be paid for, the time during which the letter of credit shall be effective, the amount and the method of payment.

Here, too, the bank is immune from liability for the default of either seller or buyer, as long as the documents presented are, on their face, in accord with the conditions of the letter of credit.

The letter of credit has the advantage for the seller, since it assures him of timely payment. Its great disadvantage is that it compels the buyer during the whole time of its effectiveness to keep funds at the disposition of the seller, while at the same time it wealsens the buyer's position in regard to disputing payment (usually the buyer is located in a different city). Also its procedure is more complicated than that of the acceptance. The letter of credit, it is stated, is based on an acceptance of goods rather than on acceptance of documents. 
(3) The transfer. This method of payment operates like the letter of credit, with the exception that there is no control by the bank over the basis of payment, the documents to be presented, etc. The bank only establishes the identity of the remittee, and until actual payment the money is $\mathrm{m}$ the complete disposition of the remitter. The transfer is used chiefly to make payments for goods and services up to 1000 rubles and to settle financial accounts such as the payment of debts and of claims. Its advantage is that it is a speedy method of transferring funds.

(4) Commissions of payment. Intra-city trade differs from intercity trade in that, as a general rule, the intra-city purchaser takes the goods from the warehouse of the seller, otten after making payment, whereas in inter-city trade the seller is generally responsible for the delivery of the goods to the warehouse of the purchaser, often before payment. Also in intra-city trade the purchaser often participates in the selection of the goods for quality and for assortment, which is not true of inter-city trade. ${ }^{98}$ Because of these operative differences, Soviet law has made distinctions between the two types of trade in regard to terms of payment in contracts of sale. ${ }^{99}$ Thus where the acceptance form of payment is used in intra-city trade, the seller delivers the documents to the buyer directly, presenting only the demand for payment to his bank for collection. Further, other methods of payment may be used in intra-city trade, including so-called commissions to pay, checks, and planned payments.

On agreement of the seller to ship the goods without preliminary payment for them, the buyer may give to his bank a commission to pay the seller, without its being stated in the commission that the goods have been received. If the seller demands a preliminary payment, such payment may be made at a discount by the bank from the account of the seller. The bank then certifies the discount by indorsement on the third copy of the commission to pay, which is returned to the buyer. The buyer then presents a copy of the commission to pay, with indorsement, to the seller who is obliged to issue the goods against it.

The indorsement of the bank on a commission to pay is not a warrant for the receipt of the goods. The seller must verify whether the person presenting the commission is a representative of the buyer

${ }^{98}$ Cf. Aizin, Questions of Intra-City Trade, ARBITRAzH [1938] No. 2 (in Russian) 14.

99 These distinctions do not generally apply in Moscow and Leningrad, where the operative differences from inter-city trade are slight. 
and has the right to receive the goods. The seller presents the commission to pay to the bank, which verifies the signatures and the presence of sufficient funds in the account of the buyer, and deducts the required sum, returning the third copy of the commission to the payor as a receipt.

Accounts by commissions to pay are used in cases of single (spot) purchases when there are not continuous relationships between buyer and seller, or in the case of an untrustworthy buyer. They are also used where the amount to be paid is between 100 and 1000 rubles.

(5) Checks. The buyer may deliver to the seller a check, which the seller presents to the bank. The bank will not accept a check unless there are sufficient funds in the account of the payor at the moment of presentation. Used chiefly for payments under 1000 rubles, checks are expressly excluded as a method of payment in certain branches of trade (including trade in the products of grain, oil, wine and vodka, as well as industrial equipment).

(6) Planned payments. ${ }^{100}$ Buyers and sellers who are in continuous economic relations with each other may agree to settle accounts at certain times, rather than with each purchase. Planned payments may therefore be made in equal sums at intervals of not more than five days. Periodically (generally, every five, ten, or fifteen days, depending on the contract), a final accounting is made on the basis of the actual deliveries of goods for the elapsed period.

Planned payments may also be made for the first, second, and third days of a month at one-thirtieth of the cost of the monthly supply of goods under the contract, i.e., payment is made the fourth day of the month for goods actually delivered on the first day; payment is made on the fifth day of the month for the actual delivery of the second day, etc. After the lapse of a certain period, a re-accounting takes place on the basis of the actual deliveries for that period.

The method of payment is by an individual commission by the buyer to the bank for each planned payment.

Planned payments have been found convenient where there is a daily delivery of goods, as in the case of bread, vodka, kerosene, fruit, etc.

Guarantees of performance.

An essential element of contracts between Soviet state business enterprises is the penalty clause; if the parties fail to insert such a

${ }^{100}$ See Kamenskii, Periodic (Planned) Accounts, ArbTrRazH [1938] No. 1 (in Rus. sian) 14 . 
clause, it will be supplied by Gosarbitrazh if suit is brought on the contract. The penalties for nonperformance, whether agreed on by the parties or in the absence of such agreement imposed by the court, are independent of damages. They may be measured at a percentage of the cost of the goods or the payment not made, or they may be fixed at a definite sum. Generally, it is required that penalties be proportionate to the significance of the sale, the character of the obligation, and the degree to which performance has been rendered. In the event that payment is not made on time, a penalty of .05 per cent of the sum due is imposed for each day of delay. In other types of breach, statutes may declare the measure of the penalty to be exacted in the event that the parties have not provided for it in their agreement. Where Gosarbitrazh finds that the penalties agreed upon by the parties are disproportionately high, it may reduce them.

One is struck by the resemblance between Soviet sales law and our own. Yet the differences are equally significant. The resemblance is evidence of the restoration of traditional legal values and institutions which has taken place in Soviet Russia since the mid-1930's. The differences are evidence that this restoration has not meant the abandonment of the Revolution. In fact, the integration of Soviet planned economy has itself required the increased autonomy of Soviet business enterprises and the increased initiative of Soviet businessmen. And the maintenance of a stable social order has made necessary the expression of such autonomy in orthodox legal terms. Orthodox law has been adapted to socialism and not merely accepted by it. Thus the restoration of the ancient principle that contracts must be kept has not meant the rejection of the revolutionary doctrine that plans must be followed. The two-contracts and plans-bear a polar relation to each other.

Soviet jurists and economists speak of "democratic centralism"centralization of planning but decentralization of operations. How far Soviet sales law successfully expresses this principle may perhaps appear more clearly from reports of actual cases in the Soviet Gosarbitrazh. A selection of such cases is appended.

\section{Pre-contract disputes.}

\section{APPENDIX}

[CASE 1] Armatura v. Benzostroi, Shkundin, Planned Task and Contractual Obligation, Soviet State AND LAW [1940] No. 7 (in Russian) 84, 85. Plaintiff in 1934 sold ventilators and cranes to defendant under a contract. In November 1934 defendant presented to plaintiff an application to purcliase 
in 1935 the same products. Plaintiff manufactured the products because of the presented application, but defendant refused to conclude a contract, relying on the fact that its fund for 1935 had been decreased. Plaintiff resorted to Gosarbitrazh of the Council of People's Commissars of the U.S.S.R. with a suit to compel defendant to accept and pay for the products manufactured on the basis of the application. Held, suit denied, on the ground that "an application regarding requirements for the following year is a document subject to be corrected and made detailed both by the party making the application and by planning and regulating organs and cannot be viewed as creating an obligation in the maker of the application to accept and pay for the product mentioned in the application."

[CASE 2] Chief Administration of Wood-Chemicals v. Victory of the Workers et al., Isakov, On Pre-Contract Disputes under Contracts for the Supply of Indiustrial Goods, ArbiTrazH [1938] No. 9-10 (in Russian) 35, 37. A dispute arose between plaintiff producer and defendant consumers concerning the obligation of defendants to pay additional sums which were included in the current price of plaintiff's product (acetate solvents). It was found by Gosarbitrazh that the prices for plaintiff's products were fixed by the Council of People's Commissars of the U.S.S.R. or by the People's Commissariat of Timber, and that the scale of additional sums was established directly by plaintiff; further, that no such additional sums were applied for analogous products produced by another plant. The fact that plaintiff in past years had been supplied products of a higher quality than the previously established standard was immaterial, since the new standards provided for an improvement in quality. Held, defendant consumers should pay for acetate solvents sold by plaintiff at established prices without additional sums introduced by plaintiff.

[CAse 3] Chief Administration of Car Industry of People's Commissariat of Machine Building v. Car Administration of People's Commissariat of Iron and Steel Industry, ibid. at 35. In 1937 and previously, accounts for the sale of railroad cars were carried on by special accounts opened by the People's Commissariat of Iron and Steel Industry in branches of the Prombank (Industrial Bank) at the residence of seller plants. In concluding contracts for 1938, defendant, whose point of view was strongly supported by Prombank, proposed adopting the acceptance form of accounts. Gosarbitrazh of the Council of People's Commissars of the U.S.S.R., relying upon the conclusion of the leaders of Gosbank, held: the former method of accounts should be maintained as having justified itself in practice, and as corresponding to the character of the relations between the parties as well as to the established method of financing of defendant. At the same time, in order to strengthen financial discipline, it was proposed to the parties that in their contracts they should provide for sanctions for the failure of a plant to use the funds placed by defendant in special accounts as well as for the failure of defendant to maintain these special accounts.

[CASE 4] Agricultural Sales and Procurement v. Chief Administration of Agricultural Machine Construction, ibid. Defendant demanded that pay- 
ment for so-called decentralized products be made by republican, territorial and regional bureaus of plaintiff by means of acceptance of accounts of producer plants. Plaintiff demanded that payment by made by the individual bases of plaintiff which were conducted on the basis of business accountability. Gosarbitrazh of the Council of People's Commissars of the U.S.S.R. decided in favor of defendant, in correspondence with the conclusion of the leaders of Gosbank, which guaranteed the recommended form of centralized accounts by the establishment of a corresponding method of crediting the bureaus of plaintiff. (In other cases, in the absence of special conditions, Gosarbitrazh refused the request for a centralized form of accounts.)

[CASE 5] Chief Administration of Nitrogen v. Chief Administration of Butterfat, ibid. In a pre-contract dispute over Basic Conditions of Supply, it was established by Gosarbitrazh that in the case of nonpayment of accounts by purchaser enterprise of defendant, it shall be transferred to the letter-of-credit form or accounts; and in the event of failure to open such letter of credit within four days from receipt of request therefor by seller enterprise of plaintiff, the latter shall inform defendant glavk, which shall secure the issuance of such letter of credit; and only if the glavk fails to secure such issuance, may seller enterprise decrease its sales correspondingly and exact from purchaser a forfeit, as for refusal to select the products

\section{Invalid contracts.}

['CASE 6] Western Power Plant v. Construction Co., Novitskii, Invalid Agreements, Acadeniy of ScIences of U.S.S.R., Questions of Soviet Civil Law (1945) (in Russian) 31, 43. Plaintiff bought barracks from defendant. The barracks were condemned by the city council, and plaintiff sued on defendant's failure to provide full value. Held, the contract was invalid as violating the decree of the Council of People's Commissars on the transfer of buildings and edifices by one state enterprise to another; defendant must return to plaintiff the purchase price, and plaintiff must return to defendant the barracks.

[CASE 7] Moscow Central Base of Galantereya v. Artel of Invalids Red October, ibid. Plaintiff brought suit to compel defendant to surrender 6.5 tons of swan's-down purchased by plaintiff or to pay its value. In the course of the proceedings it appeared that an illegal advance payment had been made, covered by a fictitious receipt. Gosarbitrazh, applying arts. 30 and 147 of the Civil Code, ordered defendant to pay over the amount received to the state treasury.

[CASE 8] In re Barnaulskii Timber Torg Warehouse, ARBITRAZH [1939] No. 13 (in Russian) 5. In 1938 the chief arbiter of the organization committee of the All-Union Central Executive Committee for Altai district, on the basis of a communication from the Altai district torg, examined contracts entered into by Barnaulskii Warehouse for the purchase of 40,000 birch brooms, and 260,000 sorghum whisk brooms. The chief arbiter dissolved these contracts as being "anti-state" on the ground that they would over- 
burden rail transport with the transportation over a great distance of brooms which could easily be manufactured in the Altai district itself.

[CASE 9] "The Kurdai regional consumers' union and the Khirgiz commercial timber base of Glavvostsibles concluded an agreement in the Khirgiz state bureau of commercial mediation for the sale to regional consumers' unions of 150 standard houses built of logs for the sum of 720,000 rubles. One wonders at the workers of the Khirgiz bureau who registered this agreement. It is necessary to remind them that regional consumers' unions are called to serve the population of the region with goods of everyday demand, and not to be occupied with wholesale sales of standard houses. In addition, houses are among the things unable to be an object of activity of bureaus of commercial mediation ... a purely illegal agreement ...."

"The Gorkov state bureau of commercial mediation registered an agreement between the Light Industry Construction and Cossack Communal Procurement for the sale by the former to the latter of mittens. If the bureau had verified the power of attorney of the representative of the Light Industry Construction, it would have seen that the Light Industry Construction had the right only to purchase various goods and not to enter into contracts to sell them." Lusis, On the Work of the State Bureaus of Commercial Mediation, Arbitraze [1939] No. 17-18 (in Russian) 15, 16.

[Case 10] Agricultural Machine Construction Plant First of May v. Krym A'gency of Machine Rebuilding Trust, ARBITRAzH [1939] No. 12 (in Russian) 27. Plaintiff bought a diesel generator from defendant, which had previously bought the generator from Cane Construction on the understanding that there was wear-and-tear of the diesel of 45 per cent and of the generator of 15 per cent. Plaintiff received delivery at the place of business of defendant. Finding the machine would not work at all, plaintiff brought suit for the purchase price and also for costs of demounting and transportation. It was established by experts that: (1) Cane Construction sold to defendant, and defendant to plaintiff, a diesel of another type than that stipulated in the two contracts, in consequence of which the price was increased by 67,125 rubles; (2) Cane Construction sold to defendant, and defendant to plaintiff, a generator of another system than that stipulated, in consequence of which the price was increased by 84,800 rubles; (3) some of the parts of the diesel were new, but the remaining parts were 60 per cent worn, so that restoring the diesel would require three times as much money as it was worth and would be economically inexpedient. Gosarbitrazh found that Cane Construction had deceived defendant regarding the quality of the diesel and the generator, and that defendant had accepted the incorrect data on faith, passing it on to plaintiff without verification. Held, both contracts - that between Cane Construction and defendant, and that between defendant and plaintiff-were invalid, in consequence of deception in regard to quality and price of the equipment; Cane Construction was ordered to pay to plaintiff the price plaintiff paid for the equipment, and costs of demounting and transportation were imposed in varying measure on all three organizations. ("Thus, despite the fact that the purchaser accepted the equipment 
in the place of business of the seller, and consequently should have examined it, Arbitrazh nevertheless held that the seller deceived purchaser, i.e., that he did not have the right to remain silent regarding the deficiencies of the property sold." Novitskii, op. cit. supra CASE 6, at 70.)

[CASE 11] Chief Administration of Cotton Industry v. Leningrad Commercial Port, Arbitraze [1940] No. 5-6 (in Russian) 28. Plaintiff stored cotton in warehouses of defendant. Part of the cotton was destroyed by fire. In a suit for damages, defendant raised the following defenses: (a) the cause of the fire was not established by the police investigation, and none of the employees of the port were charged with criminal liability; (b) it did not appear that any act or omission of defendant caused the fire; (c) spontaneous combustion of the cotton was not excluded as a possible cause; (d) the contract between plaintiff and defendant did not provide for the responsibility of the port in such case; (e) certain special laws (Code of Maritime Commerce, Statute on Storage) free the debtor from responsibility in case of fire; (f) fire protection in the Leningrad port is in the hands of special organizations and not of the port. Held, insofar as the cotton was accepted by the port for storage, under contract, the port bears responsibility for preserving and maintaining the goods, independently of whether or not special terms were contained in the contract regarding such responsibility; the burden was on the port to show that it could not have averted the destruction of the cotton; defendant is liable for all damage caused by the fire within the boundaries of the port, but it is not liable for damage caused to the cotton outside the territory of the port by the plaintiff's failure to take timely measures to sort the cotton. " It is impossible to doubt that Gosarbitrazh had in front of it the text of art. 118 of the Civil Code. In full correspondence with that article, Gosarbitrazh held: (1) the debtor is freed from liability if he could not avoid the losses; (2) the burden of proof lies on the debtor; (3) the debtor is not hable for losses caused by the creditor's own fault." Agarkov, On the Question of Contractual Responsibility, AcADEMry of Scrences of tere U.S.S.R., Questions of Soviet Civil LaW (1945) (in Russian) 114, 119.)

\section{Terms of the contract.}

[CASE 12] Procurement-Sales Bureau Lengormestprom v. Leningrad Bureau of Lenpromtekhtiazh, ARBITRAzH [1938] No. 23 (in Russian) 26. Suit for 306,000 rubles, the purchase price of 1,050 ventilators \#3 manufactured by plaintiff under contracts with defendant, plus 11,780 rubles penalty sanctions for defendant's refusal to accept the products at the warehouse of plaintiff. Defendant claimed that plaintiff in violation of the contract had not sent it the technical terms or technical description of the ventilators, despite repeated requests therefor, and that the ventilators which plaintiff offered were of a different system of drive and a different rotation from that which defendant needed. Plaintiff rehed on a clause of the contract providing that the goods were to conform to the description in price list no. 32 of the Leningrad Council for 1937. Held, by failing to agree upon the system 
of drive of the ventilators, the parties had not established the very object of the contract; in addition to the failure to agree on an essential term of the contract, the goods did not conform to those provisions which had been agreed upon. Suit denied.

[CASE 13] Leningrad Sour Milk Products Plant v. Leningrad Combine of Dining Rooms, Restaurants and Cafes, Arbitraze [1938] No. 11-12 (in Russian) 37. Plaintiff supplied defendant with its products under a contract which provided that defendant should advertise plaintiff's products widely (through the press, radio and leafiets), in return for which one per cent of the price of the goods would be deducted. The contract contained no provision for defendant's accounting to plaintiff for the expenditures made for advertising plaintiff's products. Plaintiff brought suit for 82,500 rubles, which was one per cent of the price of the products sold, on the ground that defendant had not accounted to plaintiff for the expenditure of this sum. The Leningrad Regional Branch of Gosarbitrazh denied the suit on the ground that defendant was not obhiged to account for the sum, there being no provision therefor in the contract. Plaintiff petitioned the chief arbiter of the Council of People's Commissars of the U.S.S.R., who overruled the decision of the Leningrad court, condemming its "narrowly formal approach to the interpretation of the contract" and stating that defendant, having received one per cent of the price of the purchased goods for the purpose of advertising these goods, is obhiged to present to plaintiff an account concerning these expenditures regardless of whether the contract expressly so provided or not. Otherwise, "there is no assurance that defendant fulfilled its obligation. Therefore plaintiff has the right to receive back the sums not expended for the purpose provided."

[Case 14] Belotserkov Auto-Tractor Repair Plant One May v. Chief Administration of Machine Construction, ARBITRAzH [1938] No. 22 (in Russian) 22 . Suit for 54,495 rubles penalty sanctions for modification by defendant of contract of Dec. 13, 1937, it being claimed that defendant unilaterally decreased his order under the contract by 1,211,000 rubles. On May 13, 1938 the parties concluded an agreement concerning a decrease in the quantity of materials to be sold but failed to agree on the question of sanctions for the modification made. Gosarbitrazh denied suit, holding that by the supplementary agreement of May 13, the parties modified the contract by mutual consent.

\section{Quality.}

[CASE 15] Siberian Paper Factory of Peoplo's Commissariat of Timber v. Chief Administration of Paper Machine Construction and Paper Factory Volodarskii, ArbitrazH [1939] No. 11 (in Russian) 28. The Paper Machine Construction Trust, whose legal successor is defendant glavk, sold a pergament machine to plaintiff. After setting the machine in operation, plaintiff discovered that a whole series of parts were worn out, causing the machine to work at lowered speed, with demurrage, and to produce a poor quality of product, "by all of which was brought to plaintiff and to the na- 
tional economy much loss and damage". It appeared that the machine was designed by the Paper Machine Designing Co. of the People's Commissariat of Timber under contract with the Paper Machine Construction Trust which was the general supplier of the machine. The machine was manufactured by the Volodarskii Paper Factory of the People's Commissariat of Timber, which had contracted with aforementioned Trust to manufacture such machine though it was established by expert testimony that the Volodarskii factory was completely unadapted for such a complex and expensive task. A series of essential parts were manufactured by enterprises of the Paper Machine Construction Trust. Held, liability must be borne by Volodarsk $\ddot{n}$ Paper Factory for the manufacture of parts of bad quahty and also for defects in assembly of the machine; for the bad quality of the parts manufactured by the enterprises of the Chief Administration of Paper Machine Construction (as legal successor to Paper Machine Construction Trust), liability must be borne by defendant glavk. Also Gosarbitrazh ordered that the People's Commissariat of General Machine Construction be signalized of the fact that defendant glavk has not until now taken measures to correct the pergament machine, which, as general suppher, it was obhiged to do.

[CASE 16] Construction Co. of Institute of Cinematography v. Peskov Quarry, ARBItrazH [1939] No. 11 (in Russian) 28. Plaintiff purchased stone from defendant quarry, having viewed the stone at the quarry. Subsequently plaintiff's experts examined the stone and concluded that in view of the high subsoil waters at the place of construction and of the high waterabsorption of the stone, it would be unsuitable for laying the foundations of the structure to be built. Plaintiff therefore brought suit for return of the purchase price paid and for expenses of transportation. Held, since the contract contained no conditions regarding the quality of stone to be supplied, since the stone of the Peskov quarry was used in other buildings and corresponded to the usual requirements of such stone, and since the stone was received by the purchaser at the quarry, the suit should be denied.

[CASE 17] Consumer of Metals Plant v. Red October Factory, ArBITRazH [1939] No. 1 (in Russian) 24. Plaintiff brought suit for 80,000 rubles damages in connection with the sale by defendant of metal of bad quality. Plaintiff presented in evidence two statements, one of March 16, 1038, the other of April 19,1938, composed with the participation of representatives of the Regional Council, and stated that defendant sent no representative to participate in the composition of the statements as requested. Gosarbitrazh, in a decision of October 21, 1938, denied the claims under the statement of March 16 on the ground that the statute of limitations had run and granted the claims under the statement of April 19, amounting to 30,000 rubles. Both plaintiff and defendant petitioned the chief arbiter for review. Held, under the terms of the contract, plaintiff, in case of nonappearance of defendant, was to compose statements of bad quality with the participation of representatives of the Chief Administration of the Metal Industry or the Chief Administration of Special Steel; therefore, a statement composed only with 
the participation of representatives of the Regional Council, which is not a specialist in questions of the quality of metal, cannot serve as foundation for declaring the metal to be of bad quality. Since the allegedly defective metal was assigned to scrap metal without consent of the seller, the suit was denied.

[Case 18] Vokt of Tsentrosoiuz v. Radiofront Plant, Arbitrazh [1939] No. 11 (in Russian) 27. Plaintiff bought 8,000 detector radio receivers with earphones from defendant for sale by consumers' cooperatives among agricultural consumers. Vokt inspected the receivers at its own warehouse and, since there was doubt as to their quality, summoned experts from the Scientific Research Institute of Communications and from the division of commercial experts of the Moscow State Bureau of Commercial Mediation. Upon a showing that the receivers were defective, plaintiff brought suit for 390,000 rubles. Defendant denied the conclusions of the experts and called in other experts from the Radio Committee, who reported that the receivers were of good quality. Gosarbitrazh ordered a new investigation by the experts of both parties jointly. It was shown by the new investigation that the receivers were of good quality and that the fault lay with the earphones with which the plaintiff's experts had tested them.

\section{Terms of payment.}

[CASE 19] Riazan Regional Textile Industrial Union v. Sepukhov Katonin Factory No. 1, ARBITRAzH [1939] No. 15-16 (in Russian) 30. Plaintiff paid defendant more than 50,000 rubles for katonin, which was accepted at the factory and for which plaintiff then gave defendant a receipt. The katonin was not shipped, and plaintiff sued in Gosarbitrazh for the sum paid. Gosarbitrazh declared the actions of the Serpukhov division of Gosbank through which the given operations were carried out, as incorrect, and brought them to the attention of Gosbank. The Moscow Regional Bureau of Gosbank, in answer to this signalization, instructed the Serpukhov division of Gosbank that demands for payment, when there is no real shipment of goods, are not subject either to acceptance for collection or for payment from the checking account of payor, even though the latter did not present a refusal of acceptance. Such demands for payment are in essence a method of commercial crediting and are a breach of the basic principles of the credit reform. The fact that a receipt was given for the goods while they were in the maintenance of the seller does not change the fictitious character of the demand for payment. It was suggested that in event such demands for payment should occur in the future, payment should not be permitted and Gosbank should impose a penalty on the seller.

(For further cases on terms of payment see CASEs 3, 4, 5, supra.)

\section{Prices.}

[CASE 20] Fuel Bureau of Flax-Timber Trust v. North-West Regional Administration of River Steamboats, ARBiTraze [1938] No. 15-16 (in Russian) 34. Defendant failed to dehiver a certain quantity of firewood to plaintiff, and a dispute arose as to the cost of the wood. Defendant proposed to 
pay at the current price establisled by the People's Commissariat of Timber -ten rubles fifty kopecks per cubic meter f.a.s. port of departure. Plaintiff demanded payment at eighteen rubles per cubic meter, which was the price at which plaintiff purchased the wood from Svirski Lumber Co. and which price was established by the Chief Administration of the Northwest Lumber Industry. Plaintiff presented a communication from the bureau of prices of the People's Commissariat of Timber of the U.S.S.R. stating: " . . the reasons for which you paid for this firewood at prices higher than the current price are unknown to us. But the fact that the Chief Admimistration of the Northwest Lumber Industry established the planned cost of this wood at eighteen rubles ... may serve as a basis for Arbitrazh to satisfy your suit at that price...." The Leningrad Regional Gosarbitrazh decided for plaintiff. On review by Gosarbitrazh of the Council of People's Commissars of the U.S.S.R., it was stated that although neither party raised the question of why defendant failed to deliver the wood and although the lower court did not discuss that question, nevertheless the outcome of the case depends on it. It appears from the documents submitted that plaintiff claims that the wood was arbitrarily seized by defendant, while defendant claims the wood was lost. If the wood was lost by defendant in transport, defendant should pay for it at the current price of ten rubles fifty kopecks per cubic meter. If it was arbitrarily seized and used by defendant, then it should pay either in double measure of the current price (if a penalty clause of that kind was contained in the contract between plaintiff and defendant) or at the actual cost of the unsupplied wood to plaintiff, i.e., at eighteen rubles. On these bases, the chief arbiter of the Council of People's Commissars reversed and remanded to the Leningrad Regional Gosarbitrazh for a new trial.

[CASE 21] Nikopol Pipe Plant v. Sumskii Machine Construction Plant, Shneerov, The Establishment of Prices and Disputes over Prices in the Practice of Gosarbitrazh, ARBItrazh [1938] No. 20 (in Russian) 2. Plaimtiff sold defendant newly familiarized nonrustable pipe at the approxinate price of 30,000 rubles per ton. For fifty tons of pipe sold from May to July, plaintiff received more than one and one-lialf million rubles. At the end of the operating year, after having shown as profits in the yearly balance a sum of more than a million rubles, plaintiff presented its calculation of the cost of the newly familiarized product upon which basis the price of the pipe would be fixed at 10,250 rubles per ton. The pipe factory refused to return to defendant the difference between the approximate price and the calculated price, basing its refusal on the fact that the price was still not officially fixed. Gosarbitrazh ordered plaintiff to pay to defendant a milhon rubles, proposing that a further and final accounting be made when the price was officially issued. On appeal to chief arbiter, affirmed.

\section{Damages, sanctions, specific performance.}

[CASE 22] Gosnak Factory v. Krasnokamskii Cellulose-Paper Combine, Arbitrazh [1939] No. 10 (in Russian) 27. Suit for damages of $1,585,000$ rubles, for failure to supply cellulose in the first three quarters of 1938 . The $1,585,000$ rubles was comprised of the following elements: contractual sanc- 
tions for failure to supply the product, 59,500 rubles; planning, shop, and general factory expenses from demurrage of machines, 1,290,000 rubles; wages of workers, 80,300 rubles; expenditure of steam and electricity for operating of machines, 1,600 rubles; loss of steam and electricity from incomplete loading of factory, 21,300 rubles; cost of unused steam and electricity, 132,000 rubles. Gosarbitrazh of the Council of People's Commissars of U.S.S.R. found that the losses listed were based only on planning norms and not on factual data confirmed by bookkeeping documents. Further, plaintiff did not present proof that the only party guilty of causing such losses was defendant. In addition, plaintiff demanded both compensation for losses and sanctions provided by contract. Gosarbitrazh therefore ordered the directors of Gosnak Factory to re-examine the actual losses; upon such re-examination, plaintiff reduced its claims to 783,000 rubles. Gosarbitrazh found that there were other causes for these losses besides the actions of the defendant and awarded 101,000 rubles damages.

[Case 23] Machine Construction Plant K. Marx v. Dolmatov Factory, ARBITRAZH [1939] No. 17-18 (in Russian) 26. Suit for 69,572 rubles penalty sanctions for delay of defendant in concluding a local contract, which, under the general contract, should have been signed not later than March 15, 1939, whereas actually it was not signed until April 28, 1939. Gosarbitrazh of the Council of People's Commissars of the U.S.S.R. found that defendant delayed signing the local contract for the reason that not until April 26, 1939, did the People's Commissariat of Textile Industry of the U.S.S.R. issue drafts to defendant for the re-establishment of defendant factory; therefore sanctions were reduced to 27,830 rubles. Defendant filed a petition for review by the chief arbiter, who reversed and remanded for a new trial with the suggestion that the 3 rd Chief Administration of the Cotton Industry should be brought in as codefendant, since it was responsible for the delay in issuing the drafts. On retrial, the latter glavk was ordered to pay 13,915 rubles penalty sanctions; the extreme complexity of the drafts was considered in mitigation of the penalty.

[CASE 24] Eletskii Plant v. Division of Sales of Chief Administration of Metal Industry, ARBitrazer [1938] No. 5 (in Russian) 21. Plaintiff and defendant entered into a contract whereby plaintiff was to sell all its products to defendant. After ordering certain products, defendant informed plaintiff that it had decided to purchase those products elsewhere and refused to accept them. Held, defendant cannot unilaterally dissolve the contract; hence it must pay plaintiff the amount due it under the contract and must, within a certain time, issue an order for the shipment of the goods, and in all other respects make a full reckoning with the plaintiff on the basis of the contract. 